\title{
Estimation of the Social Costs of Natural Gas
}

L. A. Nieves

J. R. Lemon

December 1979

Prepared for the U.S. Department of Energy under Contract EY-76-C-06-1830

Pacific Northwest Laboratory

Operated for the U.S. Department of Energy by Battelle Memorial Institute 


\title{
NOTICE
}

This report was prepared as an account of work sponsored by the United States Government. Neither the United States nor the Department of Energy, nor any of their employees, nor any of their contractors, subcontractors, or their employees, makes any warranty, express or implied, or assumes any legal liability or responsibility for the accuracy, completeness or usefulness of any information, apparatus, product or process disclosed, or represents that its use would not infringe privately owned rights.

The views, opinions and conclusions contained in this report are those of the contractor and do not necessarily represent those of the United States Government or the United States Department of Energy.

\author{
PACIFIC NORTHWEST LABORATORY \\ operated by \\ BATTELLE \\ for the \\ UNITED STATES DEPARTMENT OF ENERGY \\ Under Contract EY-76-C-06-1830
}

Printed in the United States of America

Available from

National Technicai Information Service

United States Department of Commerce

5285 Port Royal Road

Springfield, Virginia 22151

Price: Printed Copys $\because$ Microfiche $\$ 3.00$

NTIS

-Pages Selling Price

$001.025 \quad \$ 4.00$

$026-050 \quad 54.50$

$051-075 \quad \$ 5.25$

$076-100 \quad \$ 6.00$

$101-125 \quad \$ 6.50$

$126.150 \quad 57.25$

$151-175-\quad \$ 8.00$

$176-200 \quad 59.00$

$201-225 \quad 59.25$

226-250 $\quad \$ 9.50$

251-275 $\$ 10.75$

$206-300 \quad \$ 11.00$ 


\section{8}

PNL-3091

UC-95d

ESTIMATION OF THE SOCIAL COSTS

OF NATURAL GAS

L. A. Nieves

J. R. Lemon*

December 1979

Prepared for the

U.S. Department of Energy

under Contract EY-76-C-06-1830

Pacific Northwest Laboratory

Richland, Washington 99352

*Monmouth Col lege

Monmouth, Illinois 


\section{SUMMARY}

The identification of economically efficient levels of energy consumption has been identified as a goal in the process of formulating building energy performance standards. Efficient levels of fuel consumption for building space conditioning and lighting can be determined if the total costs to society of both fuels and the resources that may be substituted for fuels in building space conditioning systems are known. To test the feasibility of providing estimates of the social costs of fuels for use in developing building energy performance standards, information regarding the social costs of natural gas is surveyed and evaluated. This report identifies components of social cost, estimates values for these components, aggregates them in a national estimate and derives values for states. These estimates could then be used in minimizing the life cycle costs of building space conditioning.

Estimation of the social cost of a fuel requires knowledge of producticn, processing and delivery costs, values of direct and indirect subsidies, administrative costs of regulation, and costs to society of environmental and health damages. Estimation of the marginal social cost of natural gas is quite difficult because the price distortions caused by taxes, subsidies and regulation totally obscure the true marginal cost. The accuracy of the estimates is also influenced by regional variations in source of supply, costs and technology, time periods over which estimates are made and the size of the marginal increments in supply analyzed. In addition, information gaps regarding environmental and health damages make these effects difficult to quantify. Social costs also vary depending on the form of the fuel; for example, LNG, has higher processing costs and potential damage costs. Even if all of these difficulties in deriving social cost estimates can be overcome, the fact that gas from various sources is combined in the distribution system makes it difficult to determine the appropriate allocation of costs at disparate delivery points.

Costs of marginal production and transmission, regulation, direct subsidization and accidental damage to life and limb are estimated for natural gas. These estimates are summed to derive a national marginal social cost estimate; this value is then weighted using recent trends in the relative levels of state and national average costs to derive marginal cost estimates for states. 
Based on the analysis described in this report, we conclude that it is feasible to derive state-level estimates of the marginal market costs of gas from existing information. Estimates that include external costs, however, are subject to a high degree of uncertainty and should be regarded as understatements of true social costs. 


\section{CONTENTS}

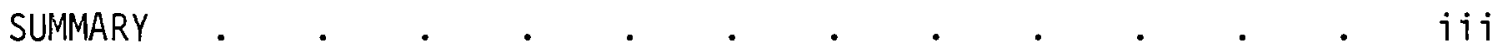

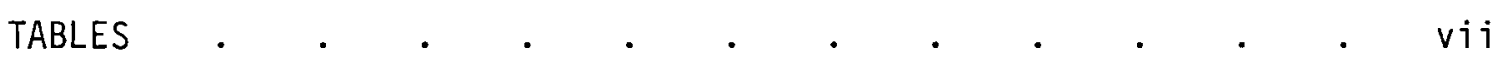

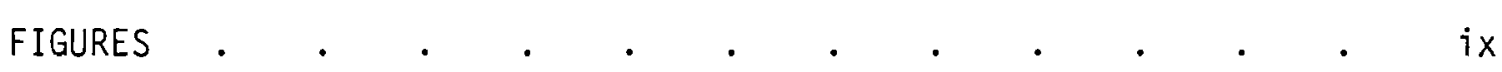

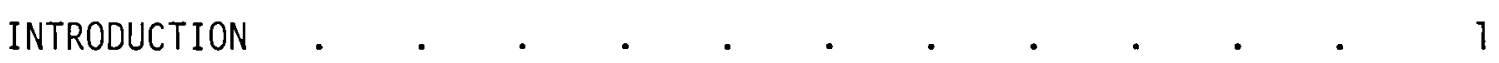

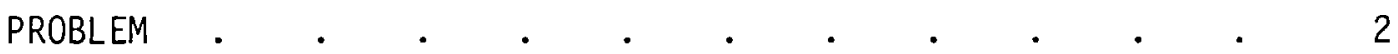

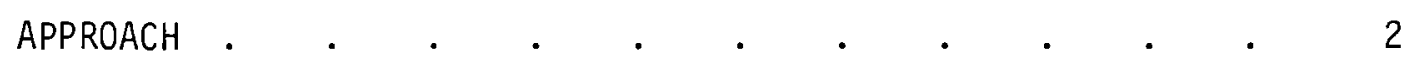

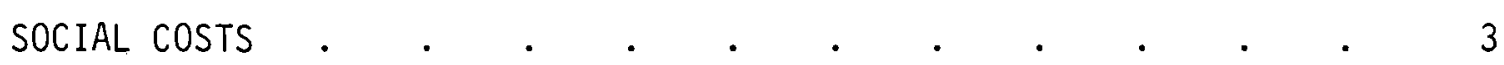

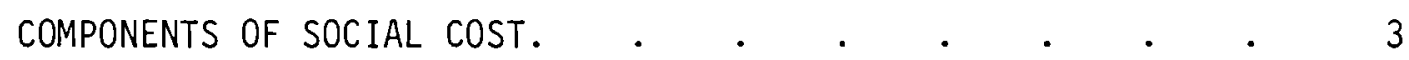

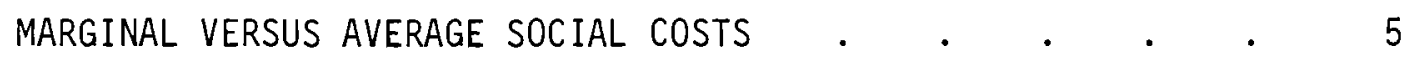

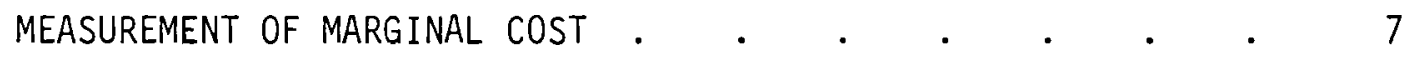

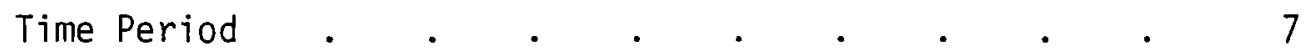

Technological Homogeneity. $\quad . \quad$. $\quad . \quad$. $\quad . \quad . \quad 7$

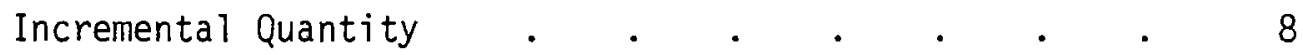

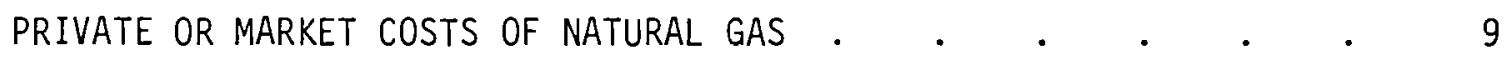

ESTIMATION METHODS FOR MARGINAL PRIVATE COST . . . . 10

Production Cost Projections . $\quad . \quad$. $\quad . \quad$. 11

Econometric Supply-Demand Analysis . $. \quad . \quad . \quad . \quad 13$

Btu Parity with Competitive Fuels . $\quad . \quad$. $\quad . \quad 18$

MARGINAL COST OF SUPPLEMENTAL NATURAL GAS SUPPLIES. • . 23

MARGINAL COST OF TRANSMISSION AND DISTRIBUTION $\quad . \quad$ • $\quad 28$

SUMMATION OF MARGINAL PRIVATE COST COMPONENTS. $. \quad . \quad$. $\quad 28$

EXTERNAL COSTS OF NATURAL GAS .

COSTS OF REGULATION •

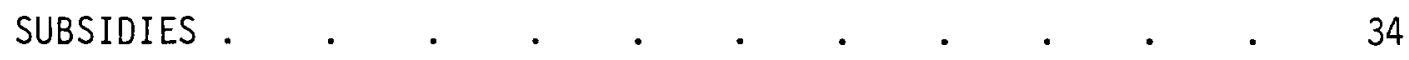


CONTENTS (contd)

Research and Development . $. \quad . \quad . \quad . \quad . \quad .36$

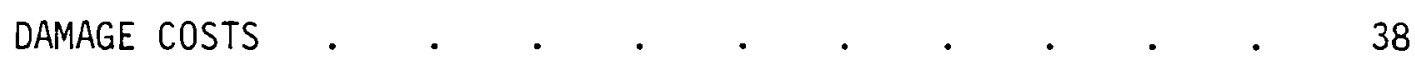

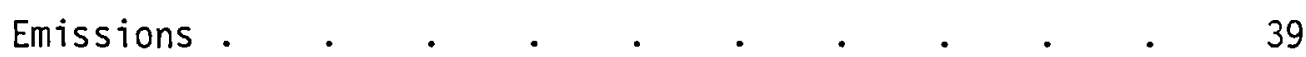

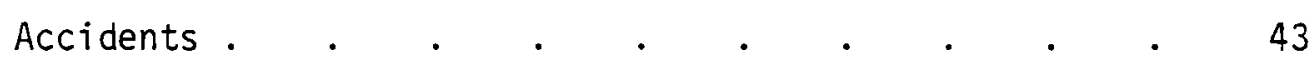

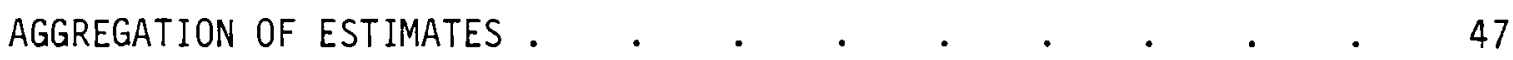

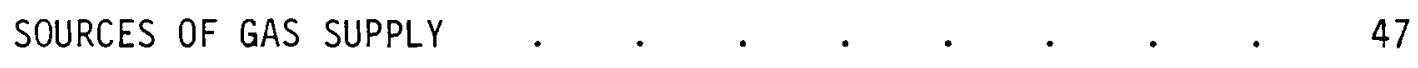

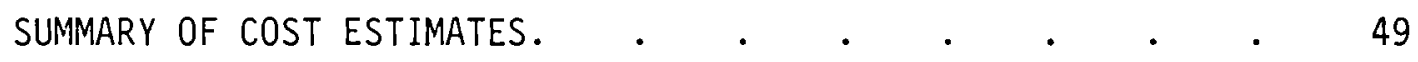

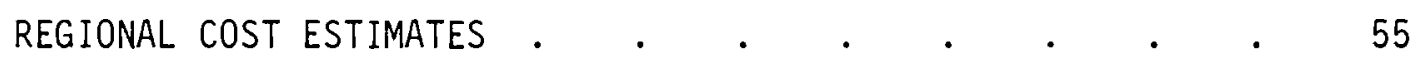

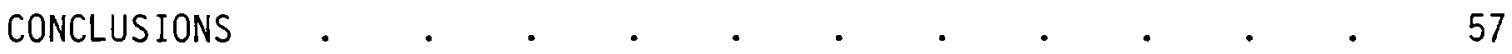

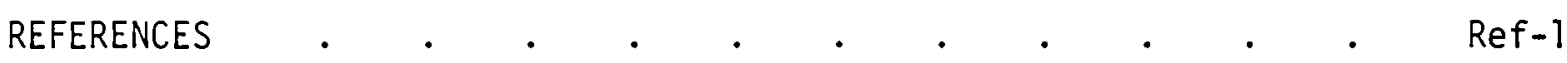




\section{TABLES}

1 Projected Price of Lower 48 States Production under

Continuing Price Regulation in 1978 Dollars . . . . 12

21985 Natural Gas Price Projections by DOE-EIA. . . . 15

3 Marginal Cost of Natural Gas in a Free Market. . . . 17

4 FOSSIL 1 National Energy Model Projections of Wellhead Gas Prices. . . . . . . . . 21

5 Projected Hellhead Price of Domestic Gas. . . . . 21

6 Retail Natural Gas Price Forecast in 1978 Dollars per

7 Price of $0 i 1$, Projected by WAES in Flexible Price Scenario . . . . . . . . . . . 23

8 AGA's Assumed Supplemental Gas Volumes and Prices . . . 25

9 Assumed Supplemental Gas Volumes and Prices Delivered to Distribution Companies. $\quad . \quad$. $\quad$. $\quad$. . . . 25

10 Calculation of U.S. Average Price of Natural Gas in 1978 Dollars . . . . . . . . . . 26

11 DOE-EIA's Assumed 1985 Volumes and Prices for Imported, Alaskan and Synthetic Gas. . . . . . . . . 27

12 Marginal Private Cost of Natural Gas . . . . . 29

13 Federal Expenditures for Natural Gas Regulation . . . 34

14 Total Research and Development Funding for Natural Gas . . 36

15 LNG Import Data. . . . . . . . . . 39

16 Estimates of Emissions from Natural Gas Processes. . . 40

17 Occupational Accident Rates for Extracting, Gathering,

18 Total Fatalities and Injuries Related to Natural Gas

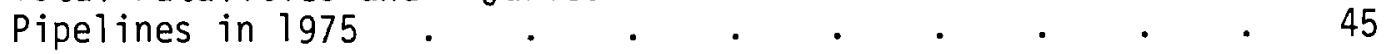

19 Imports of Natural Gas to the United States, 1970-1977 . • 49 


\section{TABLES (contd)}

20 Estimated Gas Consumption for States by Source, 1974 • 51

21 Projected Costs of Natural Gas Regulation . . . . 52

22 Projected Cost of Natural Gas Subsidization . . . . . 53

23 Summary of Fatality and Injury Rates for Natural Gas Processes. . . . . . . . . . . . . . 54

24 Social Costs of Natural Gas Related Fatalities and

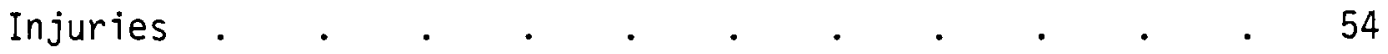

25 Summary of Social Cost Estimates for Natural Gas . . 54

26 Derivation of Regional Marginal Residential Gas Prices per $106 \mathrm{Btu}$. .0 .0 .0 .056 


\section{FIGURES}

1 Social Costs of Energy Sources. $\quad . \quad$. $\quad . \quad . \quad$. 3

2 Estimation of the Marginal Social Cost of Gas. . . $\quad 5$

3 Comparison of Marginal and Average Market and Social

Costs. $. \quad . \quad . \quad . \quad . \quad . \quad . \quad . \quad . \quad . \quad 6$

4 Trend of the Well Drilling and Equipping Cost Index in 13

5 Federal Power Commission Expenditures for Natural Gas . $\quad 35$

6 Bureau of Land Management Expenditures for Natural Gas Lands.

7 Geologic Survey Expenditures for Natural Gas . . . . . 37

8 DOE Expenditure for Natural Gas R\&D. . . . . . . . 38

9 Framework for Estimation of Social Costs Due to

Emissions . . . . . . . . . . . . . 41

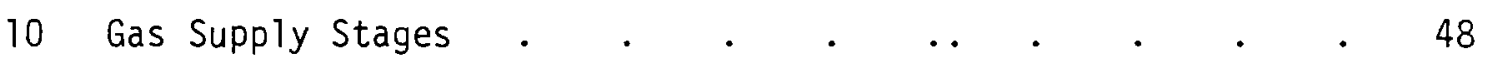

11 Natural Gas Transported in 1974 by FPC Regulated

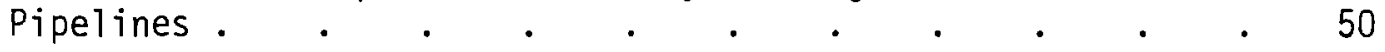




\section{INTRODUCTION}

The Energy Conservation Standards for New Buildings Act of 1976 is resulting in the promulgation of design energy budgets limiting the design energy consumption of new buildings. To aid in determining the level at which to set these design energy budgets, efficient design energy consumption levels for a wide range of building types with diverse use patterns and climatic conditions must first be identified. To be optimal the design energy consumption levels must take into account both the value of all of the energy used to provide adequate comfort levels in buildings and the relative value of the other resources that may be substituted for energy in the provision of those comfort levels.

In order to determine the design energy consumption levels that minimize the total costs to society over time of attaining requisite comfort levels in buildings, information on the marginal social cost of energy and capital inputs is needed. Much of the literature relating to the social cost of fuels avoids the question of the relative values of fuels and other resources. It has been common practice to describe the social cost of energy in terms of the average private production costs, quantities of emissions, and man/days lost due to health effects. While this approach may be useful in comparing the relative merits of alternative fuel systems, it does not provide a basis for decisions involving substitution of capital inputs for energy because it does not sum all of the costs on a comparable basis.

In a recent examination of fuel markets, prices and nonmarket costs (Nieves et al. 1979), evidence was found of market failure resulting in fuel prices that do not reflect the total social costs of the resources consumed. The pricing of energy at less than its marginal social cost leads to choices of building energy systems which result in higher annual levels of fuel consumption than would occur if all of the relevant resources were accurately or proportionally inaccurately priced. The present study has been undertaken to determine whether it is feasible to construct estimates of the marginal social cost of fuels for use in determining optimal design energy consumption levels for buildings. 
PROBLEM

The purpose of this study is to determine the extent to which it is possible to develop monetary estimates of the marginal social cost of fuels, using natural gas to test a methodology that could be applied to other fuels. This requires review of previous estimates of both market and nonmarket costs to the extent that such are available. For some components of social cost, calculation of estimates from secondary data is required. The feasibility of using these estimates to develop marginal social cost estimates for the country and for states or regions must then be evaluated.

\section{APPROACH}

In order to develop estimates of marginal social cost for use in determining minimum life cycle costs of building space conditioning, economic theory is used to develop a conceptual model of the market cost of fuel extraction and conversion. Then estimation methodologies for each component of nonmarket costs are examined to assess the applicability and validity of each methodology for our purposes. On the basis of this analysis, empirical estimates of both market and nonmarket components of social cost are aggregated to calculate a social cost estimate for natural gas.

The methodology for developing social cost estimates is presented in four major sections. The first section discusses the economic theory and assumptions upon which estimation of marginal social cost is based. In the second section several methodologies for estimating marginal market costs are analyzed and recent empirical estimates are reviewed. Then projections of national marginal market costs are presented. Nonmarket costs are estimated from secondary data where possible and are presented in the third section along with a discussion of some of the data gaps. The fourth section summarizes the preceding estimates into projections of state and national marginal social costs for natural gas. A set of conclusions about the social cost of natural gas is then presented. 


\section{SOCIAL COSTS}

The term social cost refers to the total value to society of the resources utilized in producing a good. This includes the private costs of production, that is, the producer's cost for materials, energy, labor, and capital. It also includes the value of public sector investment such as research or subsidy that reduces the production costs of the firm, pollution abatement undertaken by the public sector and any residual environmental damages borne by the public.

\section{COMPONENTS OF SOCIAL COST}

The total social cost incurred in the production of fuels, natural gas in particular, consists of the major components defined below and illustrated in Figure 1. Values for these components are estimated in the following sections in terms of the cost per $10^{6}$ Btu delivered to the building boundary.

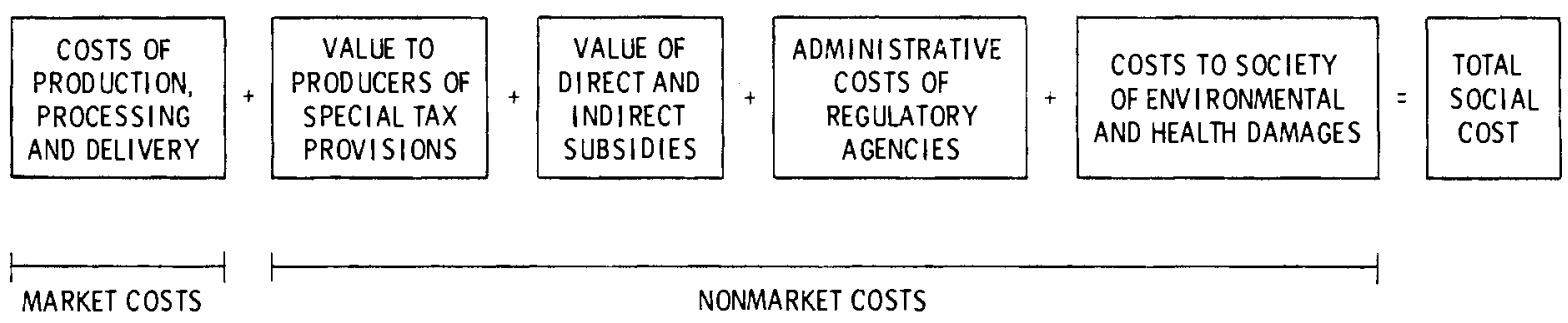

\section{FIGURE 1. Social Costs of Energy Sources}

- Private Production Costs. These are the costs of all production inputs including raw materials, capital, labor, technology, marketing, distribution, etc.

- Monopoly Pricing. The existence of monopoly power usually leads to product prices which exceed marginal production cost. A social cost reuslts due to the accompanying restriction of output quantity.

- Regulation. To the extent that regulation eliminates monopoly pricing tendencies it belongs in the category of social benefit rather than 
cost. However, any benefit gained is at the expense of administrative budgets borne by the public sector which are a social cost.

- Subsidies. Subsidies include investments and provisions by the public sector that reduce the cost of production faced by firms. These may be in the form of preferential tax rates, government funded research or risk limitation as in the case of the Price-Anderson Act. The subsidy may also be indirect, affecting an input to production such as barge transportation.

- Environmental Damages. The environmental damages associated with fuel production and conversion affect land, water and air. They may result in reduced production of flora and fauna, accelerated deterioration of materials, or loss of amenities. Each of the effects may be considered to generate a social cost.

- Health Damages. These reflect the effects of environmental damages on human health. These may contribute to early mortality, increased susceptibility to disease, genetic defects or long-term disabilities. Social costs ensue from the resultant medical expenses, reduced productivity, pain, suffering and anxiety.

The theory which forms the basis for estimation of the marginal social cost of natural gas is illustrated in Figure 2. The price estimates shown in tables in succeeding sections will be developed using this theory.

In Figure 2, $S$ represents the supply curve incorporating marginal private costs, $S^{\prime}$ represents the supply curve for gas incorporating marginal social costs and $D$ represents demand. Point $\underline{A}$ represents an estimate of the unregulated market price $\left(P_{2}\right)$. However, given the distortion caused by government regulation that holds old gas prices at $P_{1}$ and influences the quantity produced, higher cost supplies than $\underline{A}$ are exploited. The marginal (private) cost of these latter sources may be considerably higher than $P_{2}$. This price, however, does not reflect externalities. The procedure of this study is to estimate $\underline{A}$, then add on externality costs. The resultant price, $P_{4}$, then ideally requires adjustment for supply and demand elasticities to compute the marginal social cost, $P_{3} \cdot P_{3}$ is the relevant marginal social cost because 


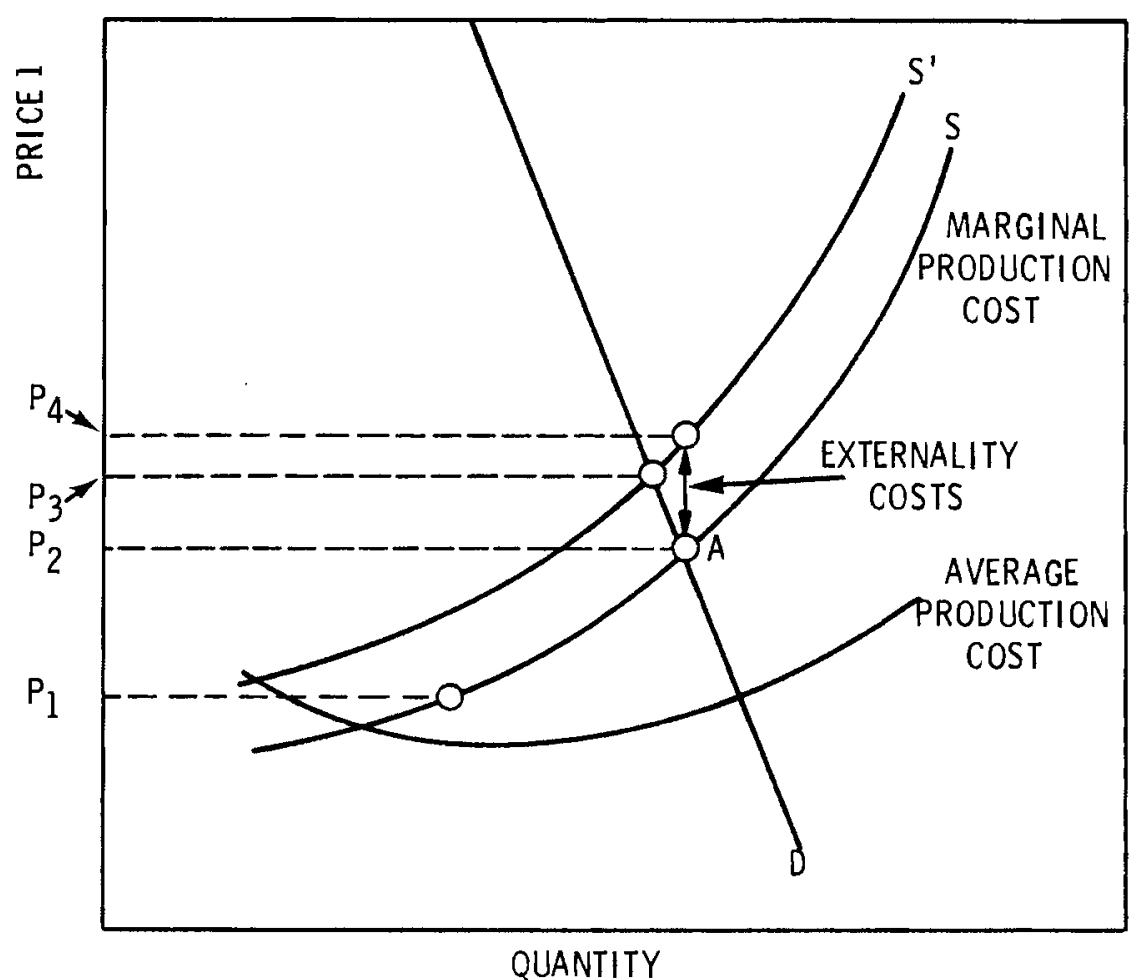

FIGURE 2. Estimation of the Marginal Social cost of Gas

it is associated with the quantity of natural gas that would actually be purchased. As illustrated in the figure, efficient allocation of resources from a societal viewpoint occurs where demand intersects the supply curve based on social costs $\left(S^{\prime}\right)$; this point is $P_{3}$.

MARGINAL VERSUS AVERAGE SOCIAL COSTS

Minimization of the total cost to society of maintaining given comfort levels in buildings requires knowledge of the marginal social cost of the resources consumed. For fuels, estimation of marginal social cost is complicated by the fact that market failure has been pervasive and longstanding. Regulations affecting both price and quantity of natural gas, for example, totally obscure the marginal cost. Secondary data related to fuel production externalities generally allow computation of average cost at a given level 
of production--not marginal cost. Because of this problem, average cost estimates are used as proxies for marginal cost in some portions of the social cost estimation procedure.

If firms are operating in a range of production where average social costs are relatively constant, average cost will provide a good estimate of marginal cost. In Figure 3 there is a range of output quantities between $A$ and $B$ over which the marginal and average market costs do not differ greatly. If the ratio of nonmarket costs (E) to market costs is also nearly constant, average social cost will be a good proxy for marginal social cost. However, when the external costs increase with the output level as shown in Figure 3 , marginal and average social cost may differ significantly over the same range of production $A$ to $B$. The difference $\left(E_{2}\right)$ between marginal social and private costs is much greater at the higher production level $B$ than at level $A$. It is more likely that $B$ represents our current situation than does $A$. External costs of producing exhaustable resources can be assumed to be increasing; resource deposits are usually exploited in order of their quality and amounts of wastes and contaminants increase as quality declines.

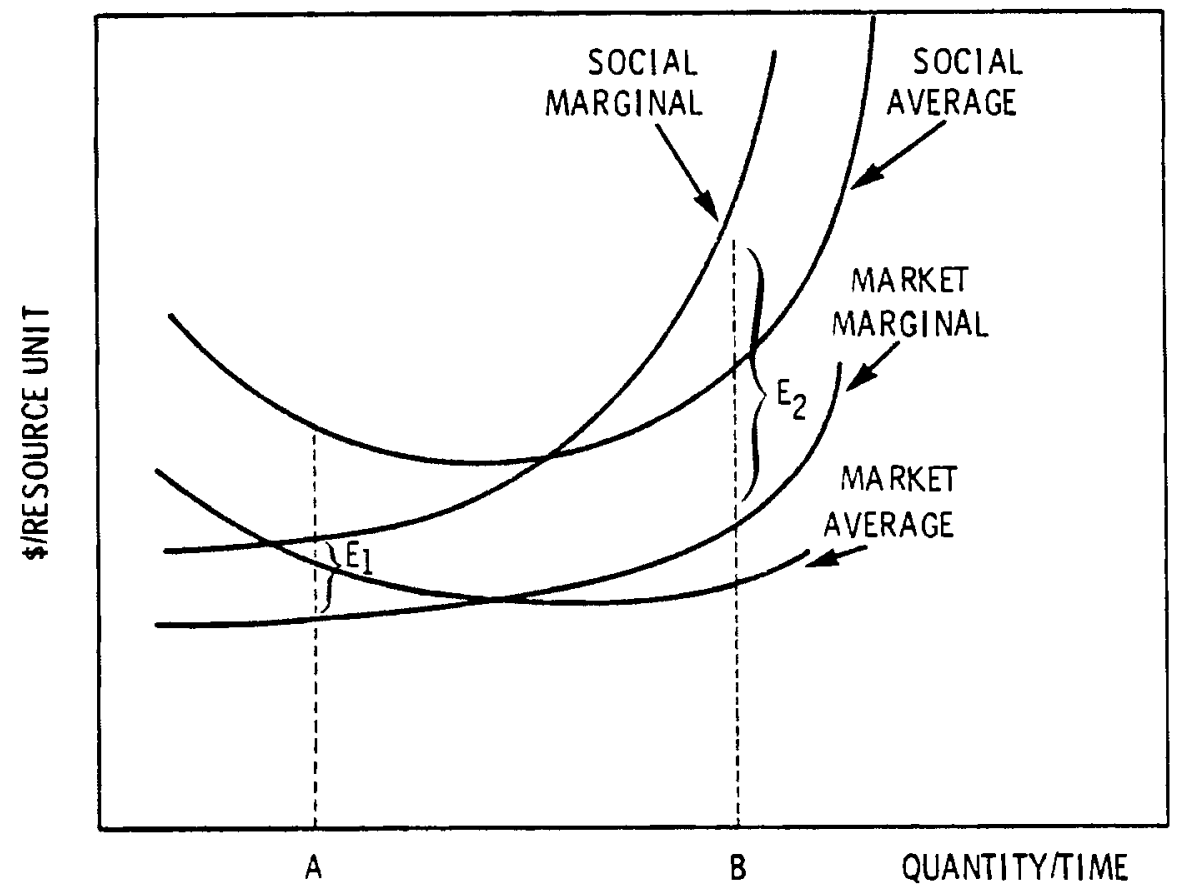

FIGURE 3. Comparison of Marginal and Average Market and Social Costs 
The social cost estimates in this study are derived from marginal private costs and average external costs. Since average private costs of fuels are increasing in real terms, our current production level is more likely to be represented by $B$ than by $A$. As a result the use of marginal private costs and average external costs probably significantly understates the true marginal social costs at current production levels. Thus, the estimates developed in this study are conservative estimates of marginal social cost.

\section{MEASUREMENT OF MARGINAL COST}

Estimation of the marginal cost of natural gas production for the nation requires resolution of several issues that are implicit in the definition of marginal cost as the cost of an additional unit of output. Empirical application of the definition assumes a specified period of time, technological homogeneity within the industry sample, and specification of the size of the output unit whose cost is to be estimated. A discussion of each of these issues and their treatment in this study follows.

\section{Time Period}

Since the purpose of this study is to determine the feasibility of developing marginal cost information for use in minimizing the life cycle costs of buildings, and since the useful life of a building is expected to be longer than the period required for capacity change in the gas industry, long-run marginal costs are estimated. These estimates will differ from estimates of marginal cost in the short-run (in which production capacity cannot be changed). This difference is particularly important in the near future in which very high marginal cost supplies are being developed due to the incentives of the regulatory structure and the effects of other governmental policies such as the exclusion of Mexican gas. Use of long-run marginal cost has the effect of smoothing the fluctuations that will occur in short-run marginal costs.

\section{Technological Homogeneity}

Estimation of marginal cost for the nation involves aggregation of marginal costs for regions with varying marginal sources of supply and differing technologies and cost structures. Indeed there is no one source of supply which 
is the marginal source in a majority of states, unless it is an expansion of conventional field gas production. Thus, to develop estimates of national marginal cost, we aggregate a wide range of regional marginal costs.

\section{Incremental Quantity}

Marginal cost estimates will vary depending on whether the relevant change in output quantity is the last cubic foot of expanded gas supply or the last trillion cubic feet. The larger the quantity considered, the lower the resulting marginal cost estimate wi11 be because of the effects of averaging. In this study the marginal cost estimates are based on the expected contribution from all supply sources to the total incremental change in quantity supplied in each period considered.

The marginal cost estimates developed in this study are long-run estimates based on gross changes in supply, aggregated across regions with differing gas supply mixes. Thus, the U.S. marginal cost estimates presented are actually a form of volume-weighted average marginal cost. 


\section{PRIVATE OR MARKET COSTS OF NATURAL GAS}

A first step in the estimation of the marginal social cost of natural gas is the computation of the marginal private (market) cost. As an outline to the following sections, the next paragraphs present a brief overview of the methodologies used in developing marginal market cost estimates. Estimates of the future marginal cost of natural gas at the wel lhead are developed using different estimation methodologies. Because natural gas is comingled with supplemental gas supplies, the marginal cost of supplemental gas is also estimated. To the average of the marginal costs of the comingled gas is then added the marginal cost of transportation to move the comingled gas to the user's location. Finally, conclusions are reached on the likely marginal private cost of gas given the likely cost of substitute fuels.

Three methods are commonly used to project the marginal private cost of natural gas. The first method is to analyze current trends in productivity and costs of exploration, development, and production and then project these trends for future years. The second method is to perform an econometric analysis of supply and demand for natural gas to determine the equilibrium price, at which supply and demand are equal. If natural gas is assumed to resemble a competitive industry, marginal cost will equal this equilibrium market price. The third method is to assume that the price of natural gas will rise to the Btu parity price of the highest cost fuel with which natural gas competes and which is used to balance energy supply and demand, with discounts or premiums used to adjust for users' preferences.

One difficulty with the first two methods is the need to adjust estimates for the fact that recent natural gas statistics, such as the size of gas discoveries per foot drilled, may reflect government regulation of interstate prices rather than the underlying resource base. Due to the policy debate leading to the enactment of the Natural Gas Policy Act of 1978, several studies were undertaken on the equilibrium price of natural gas under a deregulated environment. Most of these studies only forecast prices to 1985 or 1990 . Projections past 1990 generally rely on the Btu parity approach. Thus the requirement for price projections relevant to building 1 ives of 30 years or more may preclude reliance on econometric estimates of deregulated prices. 
Historically, setting the price of old gas and certain classifications of new gas below competitive price levels has permitted some very high-cost marginal gas supplies to be comingled with the lower price gas and the resultant mix to be sold competitively with other fuels. Because the gas sold in the retail market is derived from a different mixture of sources in each region, the marginal cost of natural gas for the nation is best measured by a weighted average of both new conventional and new supplemental gas supplies. In this report these marginal costs will be shown separately for conventional gas and for supplemental supplies; they will be presented in the final section in a weighted manner.

In analyzing projections of the price of natural gas, the period in which the forecast was made is important. Before 1973, most models using production costs and econometric techniques attempted to capture supply differences resulting from small changes ( 1 to 3 cents $/ 10^{3} \mathrm{cf} / \mathrm{yr}$ ) in the wellhead price of natural gas. The small price variation found in the 1960 to 1972 period was consistent with this investigation. However, the variation in price was so small that price parameters should not be considered accurate. Further, the elimination of the depletion allowance, changes in the prices of competitive fuels, and inflation have significantly altered price-quantity relations. Most of the studies described in this section have been completed since 1976 and provide a reference for future marginal gas price projections. (a)

\section{ESTIMATION METHODS FOR MARGINAL PRIVATE COST}

Estimates of marginal private cost are made using three bases: production cost projections; econometric supply-demand analyses; and Btu parity with competitive fuels.

(a) The best known of the econometric models is the MIT Natural Gas Supply Model developed by Paul MacAvoy and Robert Pindyck; this model, although updated, is still largely based on the period before 1973 and is not helpful in examining future prices. Further, this model has not yet been able to analyze a deregulated price scenario; supply estimates explode with increased prices. 


\section{Production Cost Projections}

Regulatory agencies have calculated the ceiling price of natural gas so that producers can earn a "fair" rate of return on their investment. To calculate this price, they have obtained current estimates of cost components such as drilling costs, lease acquisition costs, operating costs, and carrying costs. After making assumptions as to future productivity, the ceiling price was set such that a predetermined internal rate of return was earned, based on discounted cash flow projections. These ceiling prices in turn determined costs; producers could not afford to bring on high-cost supplies unless there were special rate provisions. Basing the ceiling price on historical data always produces a lower price than the price that would result from current data.

Prices derived in this manner are distorted because certain factors, including the price of competitive fuels, demand for environmentally clean fuel and inflationary pressures, are not considered. Given the distortions resulting from this method, the projected costs are used only as verification of the costs estimated by the other methods; all methods indicate rapidly rising marginal costs of natural gas. However, if production cost projections indicated that production costs were not likely to rise rapidly (i.e., supply is easily obtainable), then the ability of world oil prices to rise rapidly in the future would be questionable.

Cost forecasting studies consistent with the methodology outlined by the FPC in Opinion 699-H have recently been made by Foster Associates and by the Federal Energy Regulatory Commission. Both indicate that the uncertainty in calculating the future cost of natural gas is substantial. The most critical of the variables and assumptions utilized is the productivity factor (reserve additions of nonassociated gas per foot of successful wells drilled). Foster Associates (1978 p. III-74) used two scenarios on productivity to handle this uncertainty. The results are shown in Table 1. 
TABLE 1. Projected Price of Lower 48 States Production under Continuing Price Regulation in 1978

Dollars $\left(\$ / 10^{3} \mathrm{cf}\right)$

New Gas

1. Price

a. High Productivity

b. Low Productivity $\underline{1985}$

1990

1995

2000

189

206

218

230

253

296

309

Source: Foster Associates 1978.

The Federal Energy Regulatory Commission (formerly the Federal Power Commission), in reviewing the ceiling prices for 1975-1976 vintage gas and in establishing ceiling prices for 1977-1978 vintage supplies, determined that use of more current drilling cost data ('75-'76) than were used in the issuance of Opinion 770-A would have resulted in an initial rate of $\$ 2.08 / 10^{3}$ cf rather than the $\$ 1.72 / 10^{3}$ cf adopted (both in 1978 dollars) (FPC 1977). Foster Associates, in a study for the Natural Gas Supply Committee, used this adjusted ceiling price plus escalation to project supplies. Their estimate (1978-1985) under these upwardly adjusted prices indicated declining production in the lower 48 states (Foster Associates 1977). All three studies that used production cost trends as the basis for projecting future costs forecast rapidly rising production costs. Further, the projected supply of natural gas decreases in those studies that made volume estimates.

Joe Parent at the Institute of Gas Technology has analyzed drilling costs on a constant dollar basis and observed that since the early 1960s these costs have increased at a rate of $4.5 \%$ per year (Parent and Linden 1979). This situation is illustrated in Figure 4 . If these costs are representative of all production costs and production costs were $\$ 1.90 / 10^{3}$ cf in 1976 (expressed in 1978 dollars), this trend suggests a 1978 price estimate of $\$ 2.07 / 10^{3} \mathrm{cf}$ based solely on production costs. 


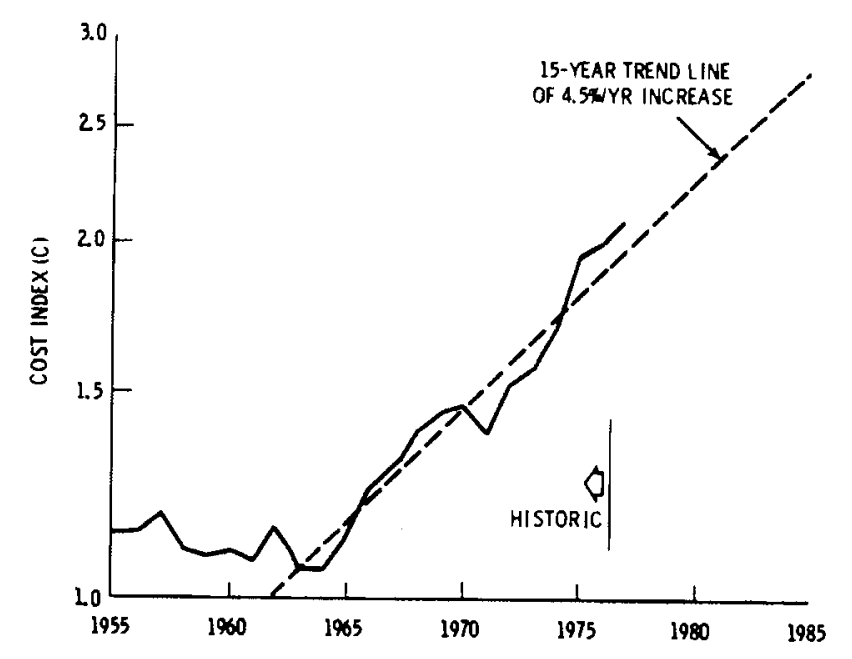

FIGURE 4. Trend of the Well Drilling and Equipping cost Index in the Lower 48 States

\section{Econometric Supply-Demand Analys is}

Econometric models are used to estimate the underlying supply and demand curves for natural gas. Simulations can be performed to predict the equilibrium price or marginal cost in the absence of regulation. Unfortunately, most models developed in the early 1970s have not been sufficiently updated to be relevant today; DOE's PIES model is a possible exception. Of the outdated models, the methodology of the MIT Natural Gas Model (MacAvoy and Pindyck) is quite appealing; (a) however, this model has only been used in recent years

(a) The marginal production costs in the MIT Natural Gas Model are dependent upon the reserve levels relative to production, so that as the reserve-to-production ratio becomes smaller, marginal costs rise sharply. The resultant equation was estimated with a term to account for noncompetitive behavior (resulting in prices higher than marginal cost), but the term was found statistically insignificant. The approximating equation for marginal development cost (MDC) is given by

$$
M C D_{t, j}=C_{0} e c_{1} q_{t, j}-C_{2} R_{t, j}
$$

where

$$
\begin{aligned}
& a_{t, j}=\text { production level out of reserves in region } j \text { at time } t . \\
& R_{t, j}=\text { proved reserves in region } j \text { at time } t .
\end{aligned}
$$

Taking logs of both sides, assuming gas price $(P)$ equals marginal cost (which it does in a competitive industry), and rearranging terms, the following form of the equation was estimated:

$$
q_{t, j}=c_{0}-c_{1} \log P_{t, j}+c_{2} R_{t, j}
$$

This methodology is somewhat similar to Zimmerman's studies on the marginal production costs of coal. Zimerman is also at MIT. 
with highly restrictive assumptions upon the future price and cost of natural gas. The data required to make accurate predictions of marginal costs have uniquely not been present in the case of natural gas because of price controls and the changing market status of natural gas in the recent past. In the future after new price-quantity relationships emerge, this methodology may be profitably used to project future costs of natural gas. The TERA model developed by the American Gas Association is a large-scale, part econometric, part judgment model of the natural gas industry; however, in recent years price and cost projections have been based on a parity rationale rather than on the interaction of supply and demand within the TERA framework. At the end of this section, estimates are presented from several studies on the price of gas wi thout distortion due to regulation. These studies generally rely upon some judgment regarding the supply-demand balance for natural gas. This section primarily reports on the Department of Energy's Energy Information Administration (DOE-EIA) models and pertinent qualifications of their results. Projections by IGT and AGA are also presented.

The Department of Energy's Mid-range Eriergy Forecasting System (formerly PIES), a series of interconnected specific fuel, sector and economy models, has been used to estimate natural gas prices. The natural gas supply model is a refinement of the original National Petroleum Council methodology; the demand model for gas relates the quantities demanded to prices and income alone. These relationships are econometrically estimated and incorporate past phenomena into all demand forecasts. Because natural gas demand in the last 10 years has been curtailed, the demand model needs to be adjusted to reflect the missing historical consumption data. The analysis by DOE-EIA in 1978 attempted to make such adjustment. While there is great uncertainty on how much and how rapidly gas demand will increase if supplies rise under the National Energy Act of 1978, the current DOE-EIA projections probably understate future gas demand. These projections are shown in Table 2. Both retail and new wellhead prices are given assuming three supply scenarios.

The understatement in the DOE-EIA model results from not capturing three factors: historical demand growth in the residential/commercial sector; future use of gas in new commercial establishments; and historical demand 
TABLE 2. 1985 Natural Gas Price Projections by DOE-EIA (1978 $\left.\$ / 10^{3} \mathrm{cf}\right)$

\begin{tabular}{|c|c|c|c|c|}
\hline & \multicolumn{4}{|c|}{ Retail Prices } \\
\hline & Residential & Commercial & $\begin{array}{c}\text { Raw } \\
\text { Material } \\
\end{array}$ & Industrial \\
\hline Low Geology/Adj. Demand & 3.33 & 3.9 & 2.60 & 2.64 \\
\hline Med. Geology/Adj. Demand & 3.31 & 3.25 & 2.55 & 2.59 \\
\hline High Geology/Adj. Demand & 3.29 & 3.15 & 2.45 & 2.49 \\
\hline
\end{tabular}

1985 New Gas Wellhead Price

Low Geology/Adj. Demand

2.81

Med. Geology/Adj. Demand

2.63

High Geology/Adj. Demand

2.36

Source: DOE-EIA 1978. Tables I and IV, Executive Summary.

growth from new industrial plants. The failure to capture historical demand makes the estimated demand seem more elastic than it actually is. Thus, when projecting future gas demand accompanied by much higher gas prices, the projected quantity demanded falls too rapidly. If DOE-EIA has failed to capture the real demand for gas, then the marginal gas prices projected by DOE-EIA for 1985 (shown in Table 2) are too low.

In their analysis of the compromise natural gas bi11, DOE-EIA (1978) indicates a supply/demand balance for gas occurring sometime between 1981 and 1985 depending on the supply response. In the high geology case, supply increases more rapidly such that supply and demand are in balance in 1981. Under all three geology (supply) scenarios, the price of new gas is so demandconstrained in 1985 that price does not change dramatically even though controls are lifted on the price of new gas. Specifically, the new wellhead price of gas ranges from $\$ 2.36 / 10^{3}$ cf to $\$ 2.81 / 10^{3} \mathrm{cf}$ in 1978 dollars and the average wel thead price of gas ranges from $\$ 1.76 / 10^{3}$ cf to $\$ 1.84 / 10^{3} \mathrm{cf}$.

The projected new wellhead gas prices in 1985 in the DOE-EIA analysis represent lowest likely prices. Three considerations support this contention. First, the methodology used by DOE-EIA to adjust gas demand has a downward bias. 
Second, on a parity basis, projected prices of competitive fuels are considerably above those projected for gas. Third, recent projections by others of gas demand lie above DOE's supply projections. An example of the second consideration can be illustrated using recent projections by the Institute of Gas Technology (1977). In the IGT report, Number 2 fuel $0 i 1$ in the residential market is projected to reach $57.9 \$ /$ gal or $\$ 4.19 / 10^{6}$ Btu in 1985 . (a) Also, transmission and distribution costs were projected at $\$ 1.76 / 10^{3}$ cf for the residential market, suggesting an average wellhead price of gas of $\$ 2.43 / 10^{3}$ cf would be reasonable. Comparing the oil price projections of DOE and IGT shows lower DOE projections of $\$ 3.33 / 10^{3}$ cf versus $\$ 4.19 / 10^{3}$ cf for retail residential gas price and $\$ 1.91 / 10^{3}$ cf versus $\$ 2.43 / 10^{3}$ cf for average wellhead price respectively.

In addition DOE supply projections are lower than most demand projections. Other projections reported in the next section are comparable to the IGT values. Recent gas demand estimates by AGA (1978) suggest 23 to $28 \times 10^{12}$ cf may be needed by 1985. Other estimates for 1990 range from $22.7 \times 10 \mathrm{cf}$ to $27.5 \times 10^{12} \mathrm{cf}$. As most of these are greater than the lower 48 production of 16.2 to $19.1 \times 10^{12} \mathrm{cf}$ of supplemental supplies projected by DOE-EIA, these supplies should be considered less than demand. On the basis of this evidence, it appears that shortages will continue which should drive prices higher.

Several studies undertaken in 1977 projected the new gas price in 1985 assuming deregulation. Table 3 presents the results of six of these studies. Because these studies considered the influence of both supply and demand, they are included in this section. However, while these studies generally relied on fairly elaborate econometric methodologies to project gas supplies, the demand for gas was simply assumed to be large enough to take whatever supply came on the market as long as the average price of gas was less than the price of industrial distillate or residual fuels. Thus users are assumed to shift from gas when the price exceeds fuel oils. Without an empirical basis for demand, these studies' projections may also be considered to be "parity" determined.

(a) Current prices indicate the projection by IGT is lagging actual prices. This provides further indication that DOE-EIA's projections of future gas prices are too low. 
TABLE 3. Marginal Cost of Natural Gas in a Free Market

\begin{tabular}{lll} 
& \multicolumn{2}{c}{ Marginal We11head Cost } \\
\cline { 3 - 3 } & $\underline{1980}$ & $\underline{1985}$ \\
AGA $1977 \mathrm{a}$ and $b$ & 2.65 & 2.60 \\
IGT 1977 & 3.50 & 2.85 \\
EOP 1977 & 2.60 & 2.76 \\
CBO 1977 & 3.17 & 2.80 \\
Erickson 1977 & 2.50 & 2.50 \\
Subcommittee 1977 & 3.9 & 2.81
\end{tabular}

In the IGT, CBO, and Subcommittee studies, the existence of low-priced old gas supplies permits marginal supplies to command high prices. It is assumed that pent-up demand due to prior curtailment of supplies causes an immediate short-term jump in price. This comes about as industrial users with fuel switching capabilities reenter the decontrolled market and bid the price of gas up to a parity basis with industrial distillate. Some high-cost supplies may come to the market in a manner not dissimilar to that in which various high cost SNG projects have been approved in recent years. This shortterm marginal cost is projected to decline over time as low-priced old gas sources are depleted. With the advent of the National Energy Policy Act of 1978, the start of this predicted price bubble is postponed until the 19851990 period. These high marginal costs, while reflecting prior distortion due to regulation, are valid in making society's choice between al ternative fuels in those years. The difficulty in their use lies in the short-term nature of these marginal costs. For planning purposes, the marginal cost five years after deregulation may be the best cost to compare with costs of other fuels. In a deregulated market as for a new technology, the best cost for comparison is the cost several years out once economies of production are realized.

Overall the econometric supply-demand analyses suggest a marginal wellhead cost of gas in 1985 in the range of $\$ 2.81 / 10^{3} \mathrm{cf}$ to $\$ 3.65 / 10^{3} \mathrm{cf}$. The latter is the highest price new gas can reach without the average price of gas at the 
wellhead exceeding $\$ 2.43 / 10^{3} \mathrm{cf}$. The $\$ 2.43 / 10^{3}$ cf is limiting since it is the Btu equivalent price of oil. Gas prices above this level significantly decrease gas demanded. Even if $\$ 3.65 / 10^{3}$ cf marginal supplies were developed by 1985 a decrease in marginal cost would be expected in the succeeding years as offsetting quantities of lower-priced old gas decrease. The DOE-EIA study projection of $\$ 2.81 / 10^{3}$ cf presents lower bounds on likely 1985 marginal costs. The rationale for the $\$ 3.65 / 10^{3}$ cf price as the upper bound on marginal gas supplies in 1985 is identical to the arguments used in the subcommittee's study and the IGT analysis cited in Table 3; the marginal gas cost has simply been updated.

This study estimates $\$ 3.15 / 10^{3} \mathrm{cf}(1978$ dollars) as the likely 1985 cost of marginal gas supply. There are two reasons for this. First, the pent-up demand for gas may be slow to re-emerge. Second, for a regulated public utility there is a difference between a transaction which creates a rate and one which does not. While development of substitute natural gas (SNG) and liquid natural gas (LNG) involves creation of a rate base, the purchase of conventional natural gas at high prices does not and may ultimately weaken the ability of transmission and distribution companies to compete in end-use markets and to maintain load factors. Thus, institutional pressures may hold gas price below maximum estimates.

Btu Parity with Competitive Fuels

A less involved method of computing the marginal gas cost assigns natural gas the Btu equivalent price of the competitive swing fuel adjusted for preferences. The swing fuel is the marginal fuel used to balance energy supply and demand. This method is attractive since it takes minimal time and expense. Further, due to uncertainties and possibie biases in econometric and production cost based projections, this latter technique may provide reasonable estimates of the marginal cost of natural gas. This is especially the case in distant time periods when projections are made far out of the range of current economic and resource conditions. Parity prices may also be free of regulatory distortions. On the other hand they depend heavily on the accuracy of price projections for the swing fuel. 
The price of natural gas cannot be forecasted without knowledge of the entire energy supply and demand framework. For example, the market price of natural gas is determined by the interaction of its production costs and demand, which in turn depends on the supply and price of competitive fuels. Prices of other fuels are partially influenced by the supply responsiveness of natural gas to higher prices. In a competitive industry with flexible prices, marginal cost will rise to the level of prices as production is expanded (or contracted). Thus, the specification of the price of the highest cost energy source which balances energy supply and demand indicates what the marginal cost of gas will be after discounts or premiums are added to account for differences in user preferences. Periods of disequilibria may hold gas above or below this price for a short time, but a tendency for the marginal cost to move to this competitive level is generally observed.

To project the marginal gas cost based on a parity rationale, one must first determine the marginal fuel type with which natural gas is competitive and which balances energy supply and demand, the price of this marginal fuel, and, finally, the differences in user preferences that may exist between the marginal fuel and gas. This section first describes several studies that make explicit assumptions as to the marginal fuel for which gas is a substitute, the future price of this fuel and the nature of user preferences. In the final part of this section several forecasts of $0 i 1$ prices are examined.

Natural gas is a close substitute with residual and distillate fuel oil. This close substitutability is particularly true in the industrial boiler fuel market. Many firms have dual--gas and oil--fuel capabilities; as the price of one fuel on a Btu equivalence rises above the other, the firms switch to the lower-cost fuel. This high substitutability of fuel oil with gas does not exist in either the process feedstock market or the residential fuel market. In these latter markets, gas clearly carries a premium over oil. Until gas supply has fallen such that only these latter two markets are being served, gas must remain competitive with either residual or distillate fuel 0i1. Under medium to high geology assumptions, natural gas supply may remain in the $15 \times 10^{12} \mathrm{cf}$ to $20 \times 10^{12} \mathrm{cf}$ range over the next 20 years. With supplemental supplies added, gas must capture part of the industrial boiler fuel market over the entire next $30-y r$ period given the size of the market segments. 
The current United States energy supply-demand balance uses imported oil as the marginal swing fuel. According to most studies, this current situation is generally expected to hold throughout the 1980s. Thus, the marginal cost of gas will tend to rise to a Btu equivalent price of imported oil. In the 1990s and beyond, it is expected that crude oil supply will decline such that the marginal swing fuels used to balance energy demand and supply are synthetic fuels produced from coal gasification and oil liquefaction. Under this scenario both the price of oil and gas will rise to the price of these synthetics. In the 1990s, gas and oil resource owners will change their reservation price, at which they are willing to offer their resource on the market; rents will increase; marginal costs will increase; and costs will increase due to the depletion of the resource base.

Several sources represent the general viewpoint outlined in the preceding paragraph. First, the Office of Policy and Evaluation (OPE) of the DOE has drafted a tentative formulation on future world oil prices and 1ikely wellhead gas prices under this scenario (OPE 1978, p. 136). The assumptions on oil prices are that in the near-term (1978-1985) there is little likelihood of a rise in the real price; in the mid-term (1985-2000) there will likely be a dramatic rise; and in the long-term (2000-2020) oil price is likely to stabilize at the marginal cost of a liquid fuel substitute such as shale oil, or coal liquids. Table 4 illustrates likely ranges of the average wellhead prices of gas under this scenario. In the near-term, both new and old gas prices are controlled and thus reflect regulatory distortion. In the long term, the wellhead prices projected for 2020 by the OPE's FOSSIL 1 Model reflect average prices with some quantities of lower priced old gas. Considering that controls have almost run their course, average price is expected to be closer to marginal price in the future.

A study by Foster Associates (1978, p. III-85) assumed in projecting the wellhead price of natural gas under free market conditions that gas price would approximate the price, on a Btu basis, of domestic crude oil. Some factors indicate that the value of gas should be higher than crude oil; other factors indicate that the value of gas should be lower. The value of gas increases with respect to other fuels because gas is a clean-burning fuel 
TABLE 4. FOSSIL 1 National Energy Mode1

Projections of Wellhead Gas Prices

Summary Table
(Fuel-Specific Units)
in 1978 dollars

\begin{tabular}{|c|c|c|c|c|c|c|c|c|c|c|c|}
\hline \multirow[b]{2}{*}{ Wellhead Prices } & \multirow{2}{*}{$\begin{array}{c}1975 \\
\text { History } \\
\end{array}$} & \multicolumn{2}{|c|}{1980} & \multicolumn{2}{|c|}{1985} & \multicolumn{2}{|c|}{1990} & \multicolumn{2}{|c|}{2000} & \multicolumn{2}{|c|}{2020} \\
\hline & & High & Low & High & Low & High & Low & High & Low & High & Low \\
\hline $\operatorname{Gas}\left(\$ / 10^{12} \mathrm{cf}\right)$ & $\star \star . \star \star$ & 1.03 & 1.03 & 1.26 & 1.26 & 1.41 & 1.45 & 2.10 & 1.57 & 4.14 & 3.79 \\
\hline $0 i 1(\$ / b b 1)$ & 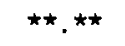 & 9.06 & 9.06 & 18.43 & 11.41 & 27.50 & $\cdot 15.24$ & 35.00 & 19.57 & 35.59 & 25.00 \\
\hline
\end{tabular}

Source: Office of Policy and Evaluation 1978.

which has great versatility for many industrial processes and does not require onsite storage. Furthermore, unlike crude oil, gas does not require the substantial cost of refining. On the other hand, crude $0 i 1$ is refined into gasoline which has a high value and the cost of transporting oil to the burner tip is less than for gas. For the purpose of the Foster study, these factors were considered offsetting. Table 5 presents the projected wellhead price of natural gas when set at approximately the domestic oil price expressed in 1978 dollars. Average retail gas prices are shown in Table 6 escalated to 1978 dollars.

TABLE 5. Projected Wellhead Price of Domestic Gas (1978 Dollars)

\begin{tabular}{|c|c|c|c|c|}
\hline \multirow[b]{2}{*}{ Year } & \multicolumn{2}{|c|}{ Domestic $0 i 1$} & \multicolumn{2}{|c|}{ Domestic Gas } \\
\hline & $\$$ /Barrel & $\Phi / 10^{6} \mathrm{Btu}^{(\mathrm{a})}$ & $\Phi / 10^{6} \mathrm{Btu}$ & $\Phi / 10^{6} \mathrm{cf}^{(\mathrm{b})}$ \\
\hline 1985 & 14.97 & 258 & 258 & 267 \\
\hline 1990 & 16.18 & 279 & 279 & 288 \\
\hline 1995 & 18.60 & 320 & 320 & 331 \\
\hline 2000 & 23.15 & 399 & 399 & 413 \\
\hline
\end{tabular}

(a) $5.8 \times 10^{6}$ Btu/barrel.

(b) $1035 \mathrm{Btu} / \mathrm{cf}$.

Source: Foster Associates 1978, p. III-85. 
TABLE 6. Retail Natural Gas Price Forecast in 1978

Dollars per 106 Btu at the City Gate

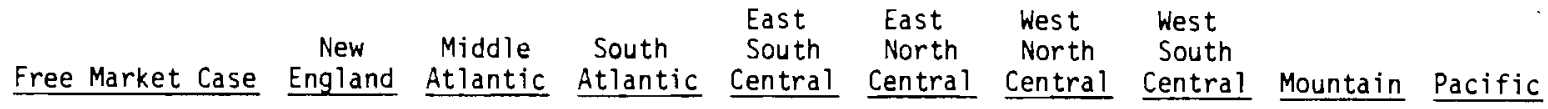

Residential Sector

\begin{tabular}{|c|c|c|c|c|c|c|c|c|c|}
\hline $\begin{array}{l}1985 \\
1990 \\
1995 \\
2000\end{array}$ & $\begin{array}{l}511 \\
539 \\
584 \\
669\end{array}$ & $\begin{array}{l}460 \\
488 \\
533 \\
618\end{array}$ & $\begin{array}{l}424 \\
452 \\
497 \\
582\end{array}$ & $\begin{array}{l}350 \\
378 \\
423 \\
508\end{array}$ & $\begin{array}{l}372 \\
396 \\
445 \\
530\end{array}$ & $\begin{array}{l}364 \\
391 \\
436 \\
521\end{array}$ & $\begin{array}{l}383 \\
435 \\
480 \\
565\end{array}$ & $\begin{array}{l}326 \\
354 \\
399 \\
484\end{array}$ & $\begin{array}{l}348 \\
376 \\
420 \\
505\end{array}$ \\
\hline \multicolumn{10}{|c|}{ Commercial Sector } \\
\hline $\begin{array}{l}1985 \\
1990 \\
1995 \\
2000\end{array}$ & $\begin{array}{l}565 \\
593 \\
637 \\
722\end{array}$ & $\begin{array}{l}487 \\
515 \\
560 \\
645\end{array}$ & $\begin{array}{l}427 \\
454 \\
548 \\
584\end{array}$ & $\begin{array}{l}359 \\
387 \\
431 \\
516\end{array}$ & $\begin{array}{l}373 \\
401 \\
446 \\
531\end{array}$ & $\begin{array}{l}364 \\
391 \\
436 \\
521\end{array}$ & $\begin{array}{l}416 \\
444 \\
488 \\
573\end{array}$ & $\begin{array}{l}336 \\
364 \\
408 \\
493\end{array}$ & $\begin{array}{l}354 \\
382 \\
430 \\
511\end{array}$ \\
\hline \multicolumn{10}{|c|}{ Industrial Sector } \\
\hline $\begin{array}{l}1985 \\
1990 \\
1995 \\
2000\end{array}$ & $\begin{array}{l}520 \\
548 \\
593 \\
677\end{array}$ & $\begin{array}{l}414 \\
442 \\
487 \\
572\end{array}$ & $\begin{array}{l}385 \\
413 \\
458 \\
543\end{array}$ & $\begin{array}{l}309 \\
337 \\
382 \\
467\end{array}$ & $\begin{array}{l}343 \\
372 \\
417 \\
502\end{array}$ & $\begin{array}{l}339 \\
367 \\
412 \\
497\end{array}$ & $\begin{array}{l}341 \\
368 \\
413 \\
498\end{array}$ & $\begin{array}{l}326 \\
354 \\
399 \\
484\end{array}$ & $\begin{array}{l}341 \\
368 \\
413 \\
498\end{array}$ \\
\hline
\end{tabular}

Source: Foster Associates 1978, p. III-90.

The American Gas Association in recent years has based its analyses of gas prices on a parity rationale with oil prices (AGA 1977, pp. 5-6). New gas prices, after controls are lifted, are expected to rise to world oil prices; world oil prices are assumed to rise only with domestic inflation. Neither the Foster Associates siudy nor the AGA analyses specify whether gas supply and demand will be in balance at these prices. Had Foster Associates used the Edison Electric Institute's gas demand projections in Economic Growth in the Future (1976), a shortage of gas would be present. This EEI study shows gas demand at $24.05 \times 10^{12}$ cf in 1980 and $30.57 \times 10^{12} \mathrm{cf}$ in 2000 . Likewise, AGA's demand projections have been higher than its own supply projections (AGA 1978).

The preceding studies indicate the importance of world or domestic oil prices in projecting new gas prices. Two world energy models (WAES and WIN)(a)

(a) See Workshop on Alternative Energy Strategies (WAES), and Dayal 1977. 
have been developed that project long-term oil prices under a number of alternative scenarios. For the purposes of projecting the marginal cost of gas, these scenarios are useful because they suggest future ranges for crude oil price with which new gas price may reach parity. Permitting a flexible price to balance supply and demand (this decreases price distortion), the WAES model with reference case assumptions shows a dramatic increase in oil prices in the 1990s. Prices of oil projected by WAES are shown in Table 7.

\section{TABLE 7. Price of 0 il, Projected by WAES in Flexible Price Scenario $(1978 \$ / \mathrm{bb} 1)$}

$\begin{array}{llll}1979 & 14.99 & 1991 & 22.21 \\ 1981 & 17.83 & 1993 & 26.07 \\ 1983 & 20.38 & 1995 & 31.68 \\ 1985 & 22.35 & 1997 & 37.41 \\ 1987 & 22.60 & 1999 & 41.65 \\ 1989 & 21.46 & 2001 & 45.71\end{array}$

Of the scenarios for the price of oil, only the Foster Associates study (1978) does not project a price approaching the cost of synthetics. Foster Associates show only a 50\% increase in the real price in the 1976-2000 period. Considering the rapidly depleting reserve base of both oil and gas, this low projection of oil price rise is rejected. On the other hand, the econometric models from which supplies have been forecasted are largely based on data from before 1974, when a new price-cost relationship developed. Therefore, this study assumes that additional reserves will be found as a result of the recent increase in exploration activities and that these new finds will delay the supply-demand imbalance by five years. The depletion of gas and oil reserves with current production levels will occur but future increases in real prices may not occur as rapidly as forecasted by WAES or FOSSIL 1.

\section{MARGINAL COST OF SUPPLEMENTAL NATURAL GAS SUPPLIES}

The gas utility industry is pursuing a program to augment natural gas production in the lower 48 states with additional sources of natural gas. These sources are comingled with natural gas in the pipeline system and make 
up part of the marginal supply. Already, natural gas is imported from Canada, synthetic natural gas (SNG) is manufactured from petroleum feedstocks, and two 1 iquified natural gas (LNG) projects are operating in the United States. Other LNG projects, Southern Alaskan gas, Mexican gas, and coal gasification plants may be expected to provide additional supplemental gas in the coming years. In general, supplemental gas projects involve long lead times due to plant and transportation construction, regulatory review, and producer/gas company negotiations.

Tables 8, 9, 10 and 11 present the projected prices and specific mix of natural gas supplies in several future periods that were assumed by AGA, Foster Associates and the Department of Energy's Energy Information Agency (1978). Once the prices are expressed in 1978 dollars, there is only partial agreement on price among these studies. For example for 1985, the projected SNG prices are $\$ 4.66 / 10^{3}$ cf by DOE-EIA, $\$ 5.63 / 10^{3}$ cf by Foster Associates, and $\$ 6.49 / 10^{3}$ cf by AGA. According to these studies supplemental supplies will make up from 13.4 to 16 percent of total supplies in 1985. Further, the percentage of total supplies from supplemental sources is expected to continually increase. Foster Associates show supplemental sources constituting $35 \%$ of the total in the year 2000.

The National Gas Policy Act of 1978 (P.L. 95-621, 92 Stat. 3350) includes an incremental pricing provision which specifies the user to whom the costs of these supplemental supplies are passed. User classifications include residential, commercial, and industrial; they are defined by size and the function for which gas is used. This incremental pricing provision causes the prices to the user to be distorted; however, after 1982 or 1983, the industrial gas price will rise to parity with distillate. Supplemental gas costs will be passed on to higher priority users--the residential customers. Thus, the actual marginal cost of gas in the mid-1980s should not reflect regulatory price distortion but actual costs.

The marginal supplemental gas sources are SNG, coal gas (also referred to as SNG), LNG, and Alaskan gas. The supply of each is projected to increase. Recent ERA decisions suggest LNG may not be allowed to increase as much as 
TABLE 8. AGA's Assumed Supplemental Gas Volumes and Prices (1978 Dollars)

\begin{tabular}{cc}
1980 \\
$\begin{array}{c}\text { Volume } \\
\text { (1012 cf } / \mathrm{yr})\end{array}$ & $(\$ / 106 \mathrm{Btu})$ \\
\hline
\end{tabular}

\begin{tabular}{cc}
1985 \\
\hline Volume & Price \\
$(1012 \mathrm{cf} / \mathrm{yr})$ & $(\$ / 106 \mathrm{Btu})$
\end{tabular}

\begin{tabular}{|c|c|c|c|c|}
\hline Alaskan & 0.1 & 2.42 & 0.1 & 3.11 \\
\hline Canadian Import & 1.0 & 3.50 & 0.9 & 4.38 \\
\hline Mexican Import & 0.4 & 3.77 & 0.7 & 6.19 \\
\hline SNG & 0.3 & 4.98 & 0.3 & 6.99 \\
\hline LNG & 0.6 & 2.10 & 0.6 & 2.53 \\
\hline Coal Gas & -- & -- & 0.2 & 6.99 \\
\hline TOTAL & $2.4(12 \%)$ & 3.54 & $2.8(15 \%)$ & 4.98 \\
\hline Lower-48 & $\underline{17.8}(88 \%)$ & & $\underline{16.3}(85 \%)$ & \\
\hline TOTAL & 20.2 & & 19.1 & \\
\hline
\end{tabular}

Source: AGA 1977.

TABLE 9. Assumed Supplemental Gas Volumes and Prices Delivered to Distribution Companies

\begin{tabular}{|c|c|c|c|c|}
\hline \multicolumn{3}{|c|}{1980} & \multicolumn{2}{|c|}{1985} \\
\hline$\left(10^{7 / 3}\right.$ & $\begin{array}{l}2^{7} \begin{array}{l}\text { (ume } \\
\text { (f/yr) }\end{array} \\
\end{array}$ & $\begin{array}{c}\text { Price } \\
\left(\$ / 10^{6} \text { Btu }\right)\end{array}$ & $\begin{array}{l}\left.{ }_{(10} / 2^{7} \text { cf } / y r\right) \\
\text { cf })\end{array}$ & $\begin{array}{c}\text { Price } \\
\left(\$ / 10^{6} \mathrm{Btu}\right)\end{array}$ \\
\hline & - & -- & 0.8 & 5.10 \\
\hline & 1.8 & 3.54 & 2.1 & 4.76 \\
\hline & 0.5 & 4.62 & 0.9 & 6.49 \\
\hline & 0.6 & 2.40 & 1.6 & 2.97 \\
\hline & 0.04 & 5.00 & 0.2 & 6.63 \\
\hline & 2.94 & 3.51 & 5.6 & 4.64 \\
\hline
\end{tabular}

\section{Alaskan}

North Ame
Imports

SNG

LNG

Coal Gas

TOTAL

2.94

0.5

2.40

5.00

5.6

0.8

5.10

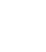

. 
TABLE 10. Calculation of U.S. Average Price of Natural Gas in 1978 Dollars ( $\$ / 106$ Btu)

$\underline{1985} \quad \underline{1990} \quad \underline{1995} \quad \underline{2000}$

Free Market Case

Lower 48 Field Price

$\begin{array}{lrrrr}\text { Price (a) } & 258 & 279 & 320 & 399 \\ \text { Weight (a) } & 0.84 & 0.79 & 0.70 & 0.66 \\ \text { Canadian City Gate Price } & & & & \\ \text { Price } & 294 & 315 & 356 & 435 \\ \text { Weight } & 0.04 & 0.04 & 0.03 & 0.03\end{array}$

SNG City Plant Price

$\begin{array}{lllll}\text { Price }^{(b)} & 563 & 474 & 510 & 554\end{array}$

$\begin{array}{lllll}\text { Weight } & 0.03 & 0.05 & 0.06 & 0.08\end{array}$

Alaskan Gas City Gate Price

Price

$\begin{array}{llll}294 & 315 & 356 & 435\end{array}$

Weight

0.05

0.05

0.11

0.11

LNG City Gate Price

Price

Weight $(c)$

Weighted Average

$\begin{array}{llll}294 & 315 & 356 & 435\end{array}$

$\begin{array}{llll}0.04 & 0.07 & 0.09 & 0.11\end{array}$

$\begin{array}{llll}269 & 294 & 337 & 416\end{array}$

(a) High production level.

(b) Average Lurgi and $B i-G a s$ process for all regions.

(c) Base case.

Source: Foster Associates 1978, Schedule III-2-2, Sheet 2 of 2. 
TABLE 11. DOE-EIA's Assumed 1985 Volumes and Prices for Imported, Alaskan and Synthetic Gas (Volumes in $10^{9} \mathrm{cf} / \mathrm{Yr}$ and Prices in $\$ / 10^{3} \mathrm{cf}$, City Gate

\begin{tabular}{|c|c|c|c|c|c|c|c|c|c|c|c|}
\hline & $\begin{array}{l}\text { N-Eng. } \\
\text { (1) }\end{array}$ & $\begin{array}{l}\text { NY/NJ } \\
\text { (2) }\end{array}$ & $\begin{array}{c}\text { Mid-At l. } \\
\text { (3) }\end{array}$ & $\begin{array}{l}\text { S. Atl. } \\
(4)\end{array}$ & $\begin{array}{l}\text { Mid- } \\
\text { west } \\
(5)\end{array}$ & $\begin{array}{l}\text { South } \\
\text { West } \\
(6) \\
\end{array}$ & $\begin{array}{c}\text { Central } \\
(7)\end{array}$ & $\begin{array}{l}\text { North } \\
\text { Central } \\
(8) \\
\end{array}$ & $\begin{array}{l}\text { West } \\
(9)\end{array}$ & $\begin{array}{l}\text { North } \\
\text { West } \\
(10)\end{array}$ & $\begin{array}{c}\text { Total } \\
\text { or Avg. } \\
\text { Price } \\
\end{array}$ \\
\hline Volume & 4.0 & 5.8 & & & 255.0 & & & 32.8 & 392.0 & 213.2 & 902.8 \\
\hline \multicolumn{12}{|l|}{ Canadian } \\
\hline Price & 2.10 & 2.10 & & & 2.10 & & & 2.10 & 2.10 & 2.10 & 2.10 \\
\hline Volume & 12.3 & 39.1 & 52.6 & 85.4 & 242.0 & 47.1 & 38.7 & 7.3 & 210.2 & 14.6 & 749.4 \\
\hline \multicolumn{12}{|l|}{ Alaskan } \\
\hline Price & 3.59 & 3.55 & 3.46 & 3.25 & 3.40 & 3.08 & 3.31 & 3.17 & 3.16 & 2.97 & 3.28 \\
\hline Volume & 25.9 & 62.1 & 40.9 & 128.8 & 143.8 & & & & & & 401.5 \\
\hline \multicolumn{12}{|l|}{ LNG } \\
\hline Price & 3.83 & 3.53 & 2.71 & 3.53 & 4.24 & & & & & & 3.72 \\
\hline Volume & 52.2 & 83.6 & 124.5 & & 273.1 & & & & 4.7 & & 539.1 \\
\hline \multicolumn{12}{|l|}{ SNG } \\
\hline Price & 4.67 & 4.67 & 4.67 & & 4.66 & & & & 4.54 & & 4.66 \\
\hline
\end{tabular}

Source: EIA 1978 .

Note: Medium geology scenario projects $16.9 \times 10^{12}$ cf of lower-48 natural gas production in 1985 . Conventional supplies then make up $86.6 \%$ of supplies and Alaskan and synthetic gas make up $13.4 \%$. 
these studies indicate. (a) As coal gasification is the highest cost source, this supplemental source may best reflect the marginal cost of the last 0.5 $10^{12}$ cf of supplemental gas supply added during the 1985 to 2000 period.

MARGINAL COST OF TRANSMISSION AND DISTRIBUTION

In projecting the marginal cost of gas at the retail level (where fuel choice is made), future trends in transmission and distribution costs must be taken into account. This analysis assumes that the rate structure of gas pipelines and distributors will not change greatly. Future changes in their costs will be caused by changes in the load factor and by increased costs of purchased fuels. Because fixed capital costs are the largest component of pipe1 ine costs and a large proportion of distribution costs, changes in load factors will mainly affect average costs. The amount of gas used in transportation increases with the amount transported though within a narrow range. Increases in future marginal costs will be primarily due to the increased cost of gas consumed in transmission.

Currently the marginal cost of transportation is calculated at $\$ 0.35 / 10^{3} \mathrm{cf}$. This estimate is an average of the marginal cost implied in a Zinder Associates study (1975) and an Institute of Gas Technology report (1977) expressed in 1978 dollars. Projected changes in this marginal cost are based on the methodology outlined in a 1978 Foster Associates study. In the latter study, total transportation costs are set equal to quantity times the expression of average transportation cost plus 0.07 times the change in the wellhead price. The computation of the marginal transportation cost of gas in 1985 and 1990 yields estimates of $\$ 0.50 / 10^{3}$ cf and $\$ 0.52 / 10^{3}$ cf respectively expressed in 1978 dollars.

SUMMATION OF MARGINAL PRIVATE COST COMPONENTS

The marginal private cost of natural gas for the average gas user in the United States has been estimated in this section. Marginal private costs include

(a) The Economic Regulatory Administration, DOE, rejected Tenneco's TAPCO LNG project December 18, 1978 and on December 21, 1978 rejected the E1 Paso II LNG project because the applications failed to demonstrate critical needs. 
both production and non-production costs and are estimated as if the market for natural gas were in equilibrium. With reference to Figure 2, the marginal costs estimated for years 1985, 1990, 1995, and 2000 are represented by $P_{2}$ or point $A$.

In 1985, the marginal cost for conventional natural gas is best approximated by the econometric supply-demand methodology. The parity price of distillate oil suggests a limit on how high the average price of gas may rise $\left(\$ 3.65 / 10^{3} \mathrm{cf}\right)$. However, the process of gas capturing new markets to a) replace the electric power market curtailed by public policy and b) dispose of additional supplies resulting from higher prices and the promised deregulated environment indicate demand may constrain new gas prices at a lower level. While DOE-EIA projected a price of $\$ 2.81 / 10^{3} \mathrm{cf}$, this study presented a rationale for a higher price of $\$ 3.15 / 10^{3} \mathrm{cf}$. It is expected that conventional gas will make up $85 \%$ of new gas supplies (see AGA analysis in Table 8 ). The marginal supplemental gas is assumed to be SNG from coal gasification which is projected to cost $\$ 4.86 / 10^{3} \mathrm{cf}$. Marginal transmission and distribution costs together are projected at $\$ 0.67 / 10^{3}$ cf in the residential sector and $\$ 0.52 / 10^{3}$ cf in the commercial sector. The resultant 1985 marginal private gas costs at the retail level for the two sectors of $\$ 4.08 / 10^{3}$ cf and $\$ 3.93 / 10^{3}$ cf respectively are shown in Table 12.

TABLE 12. Marginal Private Cost of Natural Gas $\left(1978 \$ / 10^{3} \mathrm{cf}\right)$

\begin{tabular}{|c|c|c|c|c|c|c|c|c|}
\hline & $\begin{array}{c}\text { Marginal Private } \\
\text { Well head }\end{array}$ & $\begin{array}{l}\% \text { of } \\
\text { New }\end{array}$ & $\begin{array}{c}\text { Marginal } \\
\text { Supplemental }\end{array}$ & $\begin{array}{l}\% \text { of } \\
\text { New }\end{array}$ & $\begin{array}{l}\text { Marginal T } \\
\& \text { Distribu }\end{array}$ & $\begin{array}{l}\text { ansmission } \\
\text { ion costs }\end{array}$ & $\begin{array}{l}\text { Margina } \\
\text { Retai } 1 \\
\end{array}$ & $\begin{array}{l}\text { Private } \\
\text { as cost }\end{array}$ \\
\hline & Gas Cost & Supply & Gas Cost & Supply & Residential & Commercial & Residential & Commercial \\
\hline 1985 & (2.81 to 3.65$)$ & $85 \%$ & 4.86 & $15 \%$ & .67 & .52 & 4.08 & 3.93 \\
\hline 1990 & (3.36 to 3.94$)$ & $80 \%$ & 4.43 & $20 \%$ & .69 & .54 & 4.34 & 4.19 \\
\hline 1995 & $\begin{array}{c}4.28 \\
(4.28 \text { to } 4.74)\end{array}$ & $70 \%$ & 4.93 & $30 \%$ & .75 & .60 & 5.23 & 5.08 \\
\hline 000 & 5.17 & $65 \%$ & 5.36 & $35 \%$ & .81 & .66 & 6.05 & 5.90 \\
\hline
\end{tabular}

By 1990, the potential demand for natural gas is expected to grow relative to supply such that the limitations on gas prices observed in 1985 are of negligible importance unless further restrictions on gas use are enacted. Some 
lower-priced old gas is likely to remain; thus, new gas price could exceed that of fuel $0 i 1$. The lower bound on the marginal cost of conventional gas is $\$ 3.36 / 10^{3}$ cf and is due to higher prices of $0 i 1$ and gas resulting in new supplies which will tend to limit real increases in $0 i 1$ and gas prices. The upper bound of $\$ 3.94 / 10^{3}$ cf may occur if the higher prices do not bring forth larger new supplies. This study assumes that the lower limit is more likely. Supplemental gas supplies are projected to continue to account for an increasing portion of new gas supplies and to experience some production cost economies from their 1985 level. Transmission and distribution marginal costs are projected to increase in real terms due to the increased cost of natural gas. Marginal private costs of gas in 1990 are also shown in Table 12 and are projected to be $\$ 4.34 / 10^{3}$ cf for the residential sector and $\$ 4.19 / 10^{3}$ cf for the commercial sector at the retail level.

In 1995 the proved reserve base for both natural gas and crude $0 i 1$ is expected to show depletion in spite of the incentive to exploration provided by the higher real costs. Further, lower priced old gas supplies in the United States will be minimal. Using a parity rationale, the marginal cost of gas will be constrained by $0 i 1$ at $\$ 24.80 /$ bbl resulting in a price of $\$ 4.28 / 10^{3} \mathrm{cf}$. The rate of increase in marginal cost of gas is limited over the 1990 to 1995 period due to the diminished quantities of old gas whose rolled-in costs had previously permitted marginal supplies to command a higher price. The upper bound on gas prices in 1995 is projected at $\$ 4.74 / 10^{3}$ cf which would approach the price of synthetic fuels. With diminishing gas and oil supplies, synthetic fuels may be increasingly used to balance energy demand and supply. Supplemental gas supplies are projected to constitute $30 \%$ of new gas supplies in this period and their price is projected to rise with the cost of resources. The marginal private retail costs of natural gas are projected at $\$ 5.23 / 10^{3}$ cf and $\$ 5.08 / 10^{3}$ cf in the residential and commercial sectors.

In 2000, the marginal gas cost of as well as the marginal cost of oil will approach the cost of synthetic fuels, which is projected at $\$ 5.17 / 10^{3} \mathrm{cf}$. The uncertainty in use of this estimate stems from the possibility of a technological break-through in some new energy source which would increase the supply of synthetics at lower cost. Such a development, however, is not yet on the 
horizon. Supplemental gas is expected to constitute 35 percent of new gas supplies and come on the market at $\$ 5.36 / 10^{3} \mathrm{cf}$. The marginal transmission and distribution costs rise to $\$ 0.81$ and $\$ 0.66 / 10^{3}$ cf for the average U.S. residential and commercial user. Projected residential marginal private cost of gas is $\$ 6.05 / 10^{3}$ cf while the commercial cost is $\$ 5.90 / 10^{3}$ cf at the retail level. 


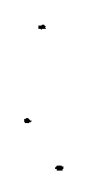




\section{EXTERNAL COSTS OF NATURAL GAS}

External costs exist whenever some of the costs associated with the production or consumption of a commodity such as natural gas are not paid by either the producers or the consumers. These external costs may take the form of dollars invested by the public and/or private sectors to eliminate undesirable effects of production or consumption. Or they may take the form of undesirable changes in goods such as air quality for which there is no market. In either case when the undesirable effects can be identified and quantified, their monetary costs can be estimated. Estimates of some of the external or nonmarket costs resulting from natural gas production, transmission and combustion follow.

\section{COSTS OF REGULATION}

In response to alleged abuses of monopoly power in the early 1900s, the Natural Gas Act of 1938 instituted regulation of interstate gas sales. Regulatory responsibility was vested in the Federal Power Commission (later the Federal Energy Resource Commission). Management of federal land use and leasing for resource development including gas is handled by the Bureau of Land Management. Portions of the budgets of both of these agencies contribute to the total social cost of natural gas production.

The budget allocations to the FPC for regulation of natural gas as recorded in the Appendix to the Federal Budget for the fiscal years 1970-1977 were converted to 1978 dollars. These are shown in Table 13 along with Bureau of Land Management (BLM) budget allocation estimates, also in 1978 dollars. The BLM estimates are based on the assumption that the proportion of total budget spent on gas is equal to the ratio of gas to total fossil fuel production on federal lands (Cone et al. 1978, p. 196).

Taken together the FPC and BLM budgets attributable to natural gas regulation have been increasing at the rate of about $20 \%$ annually in real terms. The drastic increase in the BLM budget is due to a variety of factors including the requirement of environmental impact statements. Figures 5 and 6 show the budget growth for these two agencies both in absolute terms and in cents per $10^{6}$ Btu of marketed production. 


\begin{tabular}{ccccc} 
TABLE 13. & $\begin{array}{c}\text { Federal Expenditures for Natural Gas } \\
\text { Regulation }\end{array}$ \\
\cline { 1 - 2 } & $\begin{array}{c}\text { (millions of 1978 dollars) } \\
\text { Year }\end{array}$ & $\begin{array}{c}\text { Federal Power } \\
\text { Commission }\end{array}$ & $\begin{array}{c}\text { Bureau of Land } \\
\text { Management }\end{array}$ & Total \\
1977 & 20.7 & 34.5 & 55.2 \\
1976 & 17.7 & 12.6 & 30.3 \\
1975 & 16.7 & 11.9 & 28.6 \\
1974 & 12.6 & 7.9 & 20.5 \\
1973 & 10.8 & 6.7 & 17.5 \\
1972 & 10.5 & 5.7 & 16.2 \\
1971 & 9.7 & 4.5 & 14.2 \\
1970 & 9.1 & 3.5 & 12.6
\end{tabular}

The effect of the National Gas Policy Act of 1978 on the costs of regulation is presently unknown. It is unlikely, however, that the costs will show a sharp or immediate decline given the complexity of the pricing system. Thus the present budget level may be a good indicator of costs in the near future. While the combined gas regulation costs of the two agencies totaled $\$ 55.2$ million (1978 dollars) in 1977, this was only $\$ 0.0028 / 10^{6}$ Btu of marketed production. Information on the costs of Public Service Commission regulation at the state-level was not available for this study.

\section{$\underline{\text { SUBSIDIES }}$}

Natural gas production is subsidized in a variety of ways. Until the tax revision of 1975 was passed, the depletion allowance was probably the largest source of subsidization for the gas industry. Prior to its passage Brannon (1974) estimated that the tax benefits resulted in gas prices roughly $10 \%$ lower than would have been the case without preferential tax treatment. Under the present tax regulation this price distortion due to a tax advantage has largely disappeared. Research and development funding is now the major source of subsidy for natural gas. 


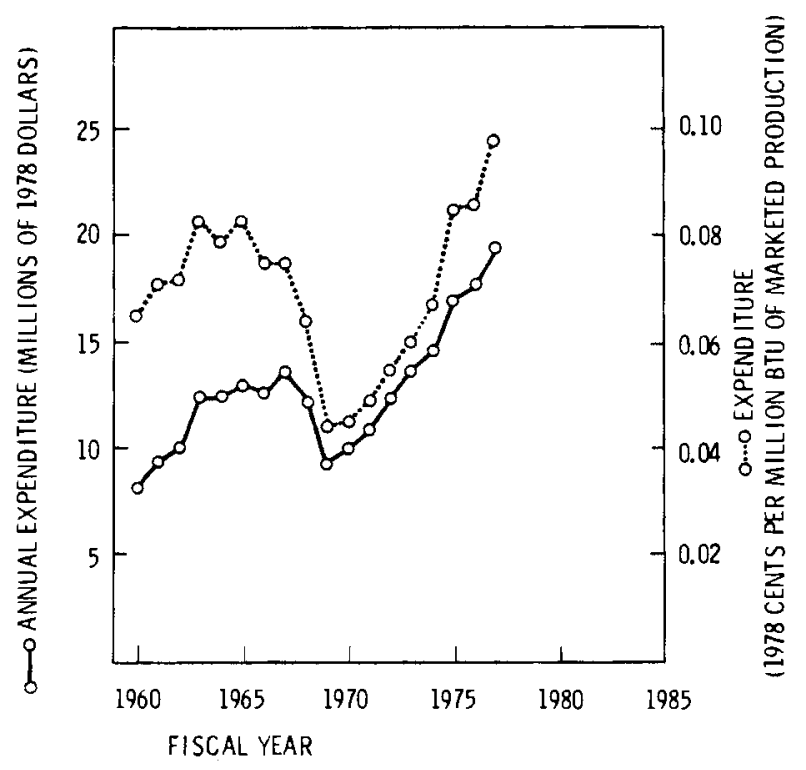

FIGURE 5. Federal Power Commission Expenditures for Natural Gas

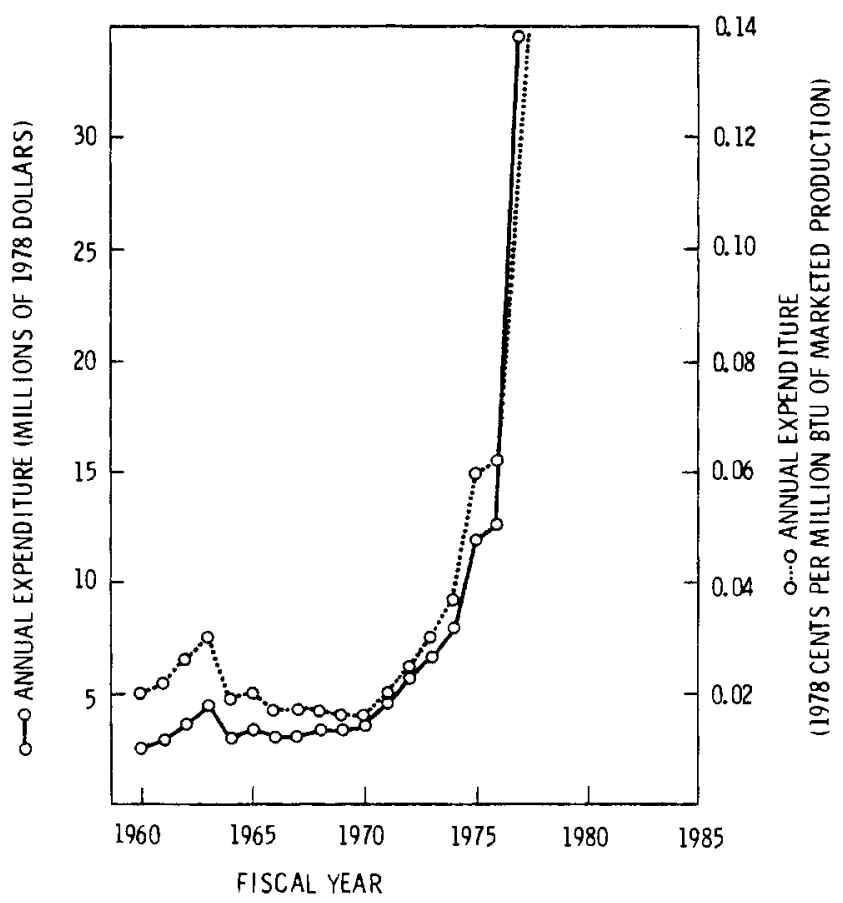

FIGURE 6. Bureau of Land Management Expenditures for Natural Gas Lands 
$\underline{\text { Research and Development }}$

Most of the publicly funded research related to natural gas is initiated by either the Department of Energy or the Geologic Survey. Though research affecting natural gas is funded by other agencies such as the Department of Agriculture, the amounts are insignificant relative to the DOE budget.

In 1978 the Department of Energy allocated 200 million dollars to gasrelated research which included $\$ 52$ million for research on the production of gas from unconventional sources such as coal and oil shale. The growth in these expenditures since 1970 is shown in real terms in Table 14. A detailed examination of the 1978 DOE program budgets revealed that $34 \%$ of the total was dedicated to gas research. This percentage was applied to the total budget to estimate the annual allocations shown in the table. Due to energy resource depletion, it is expected these expenditures will remain constant or increase in the future.

TABLE 14. Total Research and Development Funding for Natural Gas (millions of 1978 dollars)

\begin{tabular}{|c|c|c|c|}
\hline Year & $\mathrm{DOE}$ & $\begin{array}{c}\text { Geologic } \\
\text { Survey }\end{array}$ & Total \\
\hline 1978 & 200.00 & 25.00 & 225.00 \\
\hline 1977 & 167.58 & 24.95 & 192.53 \\
\hline 1976 & 137.54 & 28.03 & 165.57 \\
\hline 1975 & 121.85 & 22.13 & 143.98 \\
\hline 1974 & 28.13 & 13.72 & 41.85 \\
\hline 1973 & 21.28 & 13.72 & 35.00 \\
\hline 1972 & 16.13 & 12.34 & 28.47 \\
\hline 1971 & 15.50 & 11.95 & 27.45 \\
\hline 1970 & 11.58 & 12.30 & 23.88 \\
\hline
\end{tabular}

Source: Cone et a1., 1978. 
Data from the U.S. Geologic Survey are made available to oil and gas drilling companies to aid in siting wells. Gas composes $24 \%$ of the fossil fuels extracted from lands covered by the Geologic Survey, so that percentage of the agency budget is attributed to the social cost of gas. Table 14 shows costs for 1970 to 1978. While these estimates may overstate the gas-related costs of the Geologic Survey, it is likely that the estimate of total publicly funded research expenditures is still conservative given the omission of funding by other agencies.

The total of DOE and Geologic Survey subsidy for 1978 equals $\$ 0.0115$ per $10^{6} \mathrm{Btu}$. Figures 7 and 8 show the expenditure trends for both agencies in absolute terms and in cents per $10^{6} \mathrm{Btu}$. The rate of increase in real terms since 1975 has been close to $12 \%$ annually.

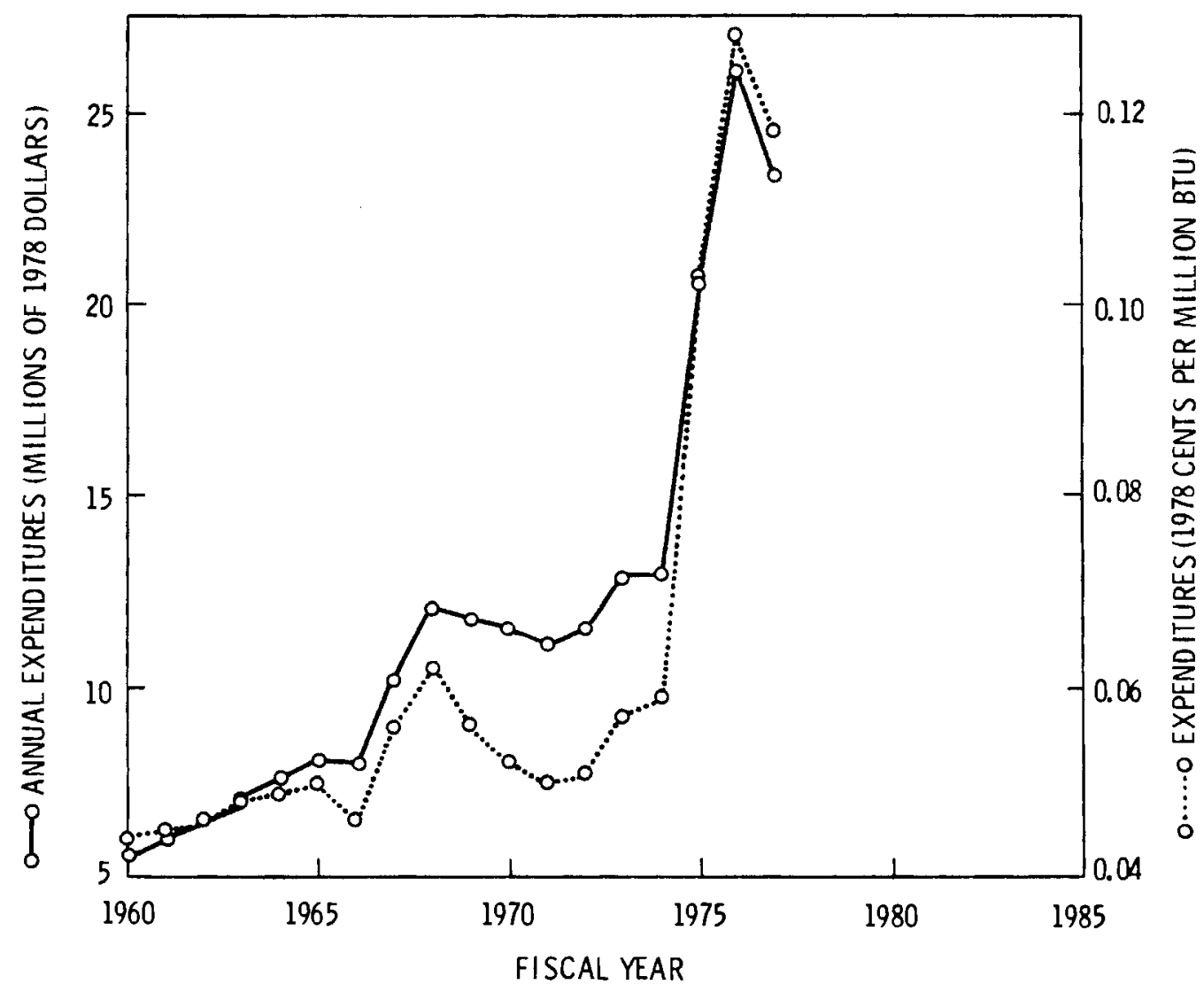

FIGURE 7. Geologic Survey Expenditures for Natural Gas 


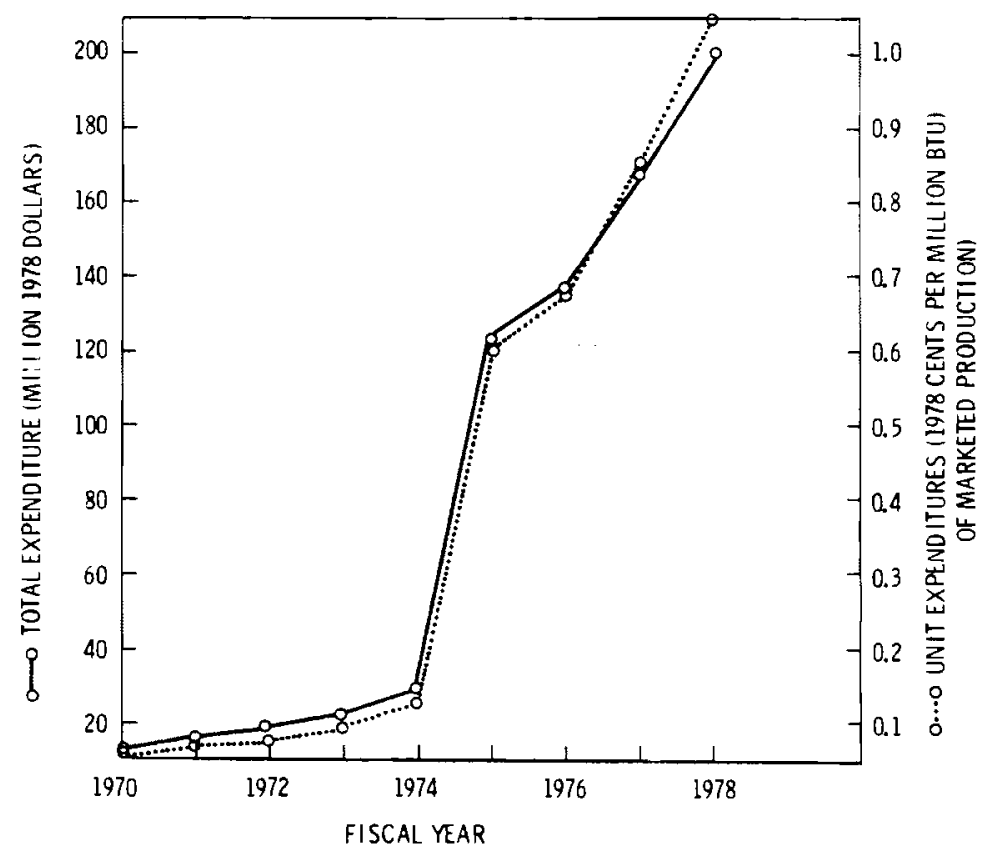

FIGURE 8. DOE Expenditure for Natural Gas R\&D

\section{DAMAGE COSTS}

Environmental and health effects of fuel production are the sources of most of the external (nonmarket) costs considered in discussions of social cost. In the case of natural gas the level of damage per $10^{6}$ Btu appears to be quite low relative to that of coal and somewhat lower than for oil. Most of the empirical estimates of damages have been carried out in situations with relatively high quantities of emissions and effluents. A linear interpolation of these damage estimates to the case of natural gas may well overstate the true damages.

Both the nature of the damages and their relative impact vary with the type of gas. Coal gasification and LNG processes involve higher damage risks than does conventional gas production. As these processes account for an increasing proportion of gas production, the total cost of damages will increase. The rate of increase in LNG importation is shown in Table 15.

If the external effects of resource production or consumption are known, then the value of those effects can be estimated. Some damages which occur as 
TABLE 15. LNG Import Data

\begin{tabular}{|c|c|c|c|}
\hline Year & $10^{6} \mathrm{cf}$ & $10^{12} \mathrm{Btu}$ & $\begin{array}{c}\% \text { of } \\
\text { Total } \\
\text { Consumption } \\
\end{array}$ \\
\hline 1977 & 11,324 & 11.5504 & 0.06 \\
\hline 1976 & 10,155 & 10.3581 & 0.05 \\
\hline 1975 & 4,893 & 4.9909 & 0.025 \\
\hline 1974 & 0 & 0 & 0 \\
\hline 1973 & 4,055 & 4.1361 & 0.02 \\
\hline 1972 & 2,262 & 2.3072 & 0.01 \\
\hline 1971 & 2,933 & 2.9916 & 0.01 \\
\hline 1970 & 757 & 0.7721 & 0.0035 \\
\hline Before 1970 & 0 & 0 & 0 \\
\hline
\end{tabular}

Source: AGA 1978.

a result of fuel production affect private property or individuals' health. Several methods are available to estimate the value of these damages which can then be multiplied by the rate of incidence of the damage to get total cost estimates. Where a common property resource such as air or water quality is affected, the estimation of social cost becomes more complex.

While estimates of the willingness of people to pay to avoid damages or to accept compensation for the damage can be made, the number of people affected is unknown in many instances. A clearly defined boundery between affected and unaffected populations is lacking; indeed it is likely that the rate of damage declines steadily with distance from the source. None of the empirical studies reviewed $^{(a)}$ went beyond estimation of willingness to pay per person to develop aggregate cost estimates.

\section{Emissions}

While there are minor damages to water and land resources as a result of natural gas production processes, most of the emissions affect air quality. Table 16 shows emissions estimates per million Btu of gas input to each

(a) See appendix of Nieves et al. (1979) for an annotated list of the studies reviewed. 
TABLE 16. Estimates of Emissions from Natural Gas Processes (a)

\begin{tabular}{|c|c|c|c|c|c|c|c|c|c|}
\hline \multirow[b]{2}{*}{$\begin{array}{l}\text { Emissions in } \\
1 \mathrm{~b} / 10^{6} \mathrm{Btu}\end{array}$} & \multicolumn{9}{|c|}{ Natural Gas Processes } \\
\hline & Extraction & $\begin{array}{l}\text { Gathering } \\
\text { Pipeline } \\
\end{array}$ & $\begin{array}{c}\text { NGL } \\
\text { Separation }\end{array}$ & $\begin{array}{c}\mathrm{H}_{2} \mathrm{~S} \\
\text { Removal } \\
\end{array}$ & $\begin{array}{l}\text { Transmission } \\
\text { Pipeline } \\
\end{array}$ & $\begin{array}{c}\text { LPG } \\
\text { Trucks }\end{array}$ & $\begin{array}{l}\text { Underground } \\
\text { Storage }\end{array}$ & $\begin{array}{c}\text { Gas } \\
\text { Holders } \\
\end{array}$ & $\begin{array}{l}\text { Residential } \\
\text { Combustion } \\
\end{array}$ \\
\hline Particulates & -- & -- & $6.70 \times 10^{-4}$ & $8.5 \times 10^{-5}$ & -- & $4.9 \times 10^{-4}$ & -- & -- & $1.84 \times 10^{-2}$ \\
\hline${ }^{N O}{ }_{x}$ & -- & $5.3 \times 10^{-3}$ & $3.76 \times 10^{-3}$ & $5.68 \times 10^{-4}$ & $2.06 \times 10^{-1}$ & $1.39 \times 10^{-2}$ & $2.44 \times 10^{-2}$ & $2.44 \times 10^{-2}$ & $4.85 \times 10^{-2}$ \\
\hline $\mathrm{SO}_{\mathrm{x}}$ & -- & -- & $1.9 \times 10^{-5}$ & $2.84 \times 10^{-6}$ & -- & $1.02 \times 10^{-3}$ & -- & -- & $5.52 \times 10^{-4}$ \\
\hline Hydrocarbons & -- & $5.54 \times 10^{-1}$ & $1.26 \times 10^{-3}$ & $1.89 \times 10^{-4}$ & -- & $1.39 \times 10^{-3}$ & -- & -- & $7.78 \times 10^{-3}$ \\
\hline CO & -- & - & $1.26 \times 10^{-5}$ & $1.89 \times 10^{-6}$ & -- & $8.46 \times 10^{-3}$ & -- & -- & $1.94 \times 10^{-2}$ \\
\hline Aldehydes & - & -- & $3.14 \times 10^{-4}$ & $4.72 \times 10^{-5}$ & -- & $2.26 \times 10^{-4}$ & -- & -- & $9.68 \times 10^{-3}$ \\
\hline Therma 1 & -- & -- & $7.75 \times 10^{-3}$ & $8.10 \times 10^{-2}$ & -- & -- & -- & -- & -. \\
\hline \multicolumn{5}{|c|}{ LNG Processes } & & & & & \\
\hline $\begin{array}{l}\text { Emissions in } \\
\text { lb } / 10^{6} \mathrm{Btu}\end{array}$ & Liquefaction & Tanks & $\begin{array}{c}\text { Storage } \\
\text { Tank } \\
\end{array}$ & Vaporization & & & & & \\
\hline Particulates & -- & $6.3 \times 10^{-5}$ & -- & $3.74 \times 10^{-4}$ & & & & & \\
\hline${ }^{\mathrm{NO}}{ }_{x}$ & $7.08 \times 10^{-1}$ & $8.74 \times 10^{-4}$ & -- & $2 \times 10^{-3}$ & & & & & \\
\hline $\mathrm{SO}_{x}$ & -- & $6.72 \times 10^{-4}$ & -- & $1.18 \times 10^{-5}$ & & & & & \\
\hline Hydrocarbons & -- & $3.08 \times 10^{-5}$ & -- & $1.57 \times 10^{-4}$ & & & & & \\
\hline $\mathrm{CO}$ & -- & $1.24 \times 10^{-5}$ & -- & $3.92 \times 10^{-4}$ & & & & & \\
\hline Aldehydes & -- & $8.7 \times 10^{-6}$ & -- & $2.16 \times 10^{-4}$ & & & & & \\
\hline Thermal & $1.03 \times 10^{-5}$ & -- & -- & -- & & & & & \\
\hline Source: Meres & & & & & & & & & \\
\hline
\end{tabular}

(a) Estimates are unlikely to be off by more than fifty percent. 
production distribution process. No data were available on emissions resulting from the extraction process, since the major instance of emissions is the release of hydrocarbons in the event of a well blow-out and this is an uncommon event. Estimates of damages attributable to gas where gas and $0 i 1$ production are associated are also unavailable.

The physical effects on property and health of the airborne emission from natural gas are similar to the effects of airborne emissions from other sources. In addition, it is virtually impossible to identify the sources of airborne emissions. As a result the estimation of damages associated with natural gas requires linkage of emission quantities to damage values through a series of complex models. The required linkage of information is diagrammed in Figure 9. Currently, the weakest links in this chain of information are the air quality or dispersion model and the damage function models.

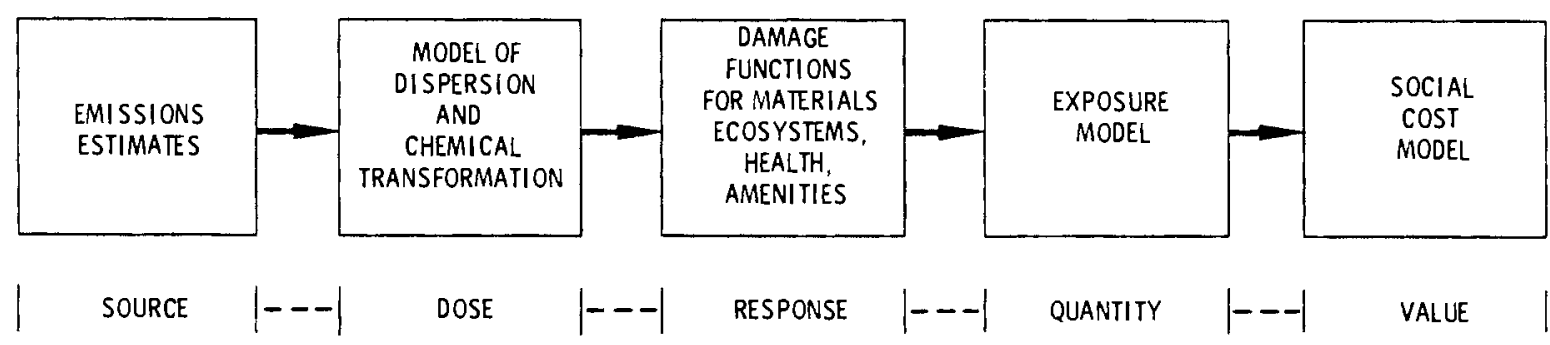

FIGURE 9. Framework for Estimation of Social Costs Due to Emissions

Emissions quantities are less critical in determining social costs than is the rate of dispersion. UTtimately the extent of the damage incurred due to emissions is a function of characteristics such as stack height, meteorological conditions, particle size and chemical reactions. Use of dispersion models in estimating the external effects of natural gas would require aggregation of many site-specific analyses so the problem has generally been handled through avoidance by limiting research scope to a single site or generic analysis (North and Merkhofer 1975). The other approach taken has been to use air quality data without any relation to emissions sources or quantities (EPA 1977). 
In spite of the lack of empirical information on dispersion rates and patterns, some generalizations can be made which are pertinent to natural gas. The combustion of gas in buildings for heating purposes is likely to be associated with a higher rate of health and property damage than combustion of the same quantity of gas at a power plant. This is due to the lack of opportunity for emissions dispersion prior to reaching concentrations of population. No complete and thorough analysis of the relative merits (based on emission damages) of gas heating versus gas-generated electric heating was found in the literature.

Damage functions describe the relationship between quantities of physical changes, in health, materials or vegetation for example, and changes in air quality. While some indication of these relationships may be gained from laboratory experiments, in many cases the relationships are too complex and reactions too slow to permit controlled experimentation. As a result the specification of damage functions is based for the most part on correlations between air quality and epidemiological, agricultural or economic time series data. Bausell (1978) recently reviewed the major epidemiological studies related to air pollution and pointed out the need for research on both pollutant interactions and exposure interactions. Our knowledge of these relationships for most of the emissions produced by natural gas is quite weak.

There have been many attempts to specify damage functions for some of the more easily identifiable airborne factors such as suspended sulfate and sulfur oxides. Discussions of the state of current knowledge in regard to these pollutants are included in Finklea (1978), Commission on Natural Resources (1975), Leung (1978), Bausell (1978) and Wilson (1978). In spite of the development of damage functions for airborne sulfur concentrations, the lack of prerequisite information on the relationship between natural gas emissions and regional air quality prevents the estimation of actual damages.

Exposure models incorporate demographic, economic and/or ecological characteristics for the area affected by the emissions. They provide the basis for estimating the quantity of expected effects as a function of the quantities of materials, plants or population in a region susceptible to damage. 
Estimates of the social cost of damages may be developed for health effects, deterioration of materials, vegetative growth impairment, reduced visibility, etc (OECD 1972). Reviews of the various methodologies currently used to construct cost estimates for a broad range of types of damages are contained in Mäler and Wyzga (1976) and Liu (1976). Since environmental damages attributable to natural gas could not be rigorously estimated within the scope of this study, the related social cost models will not be discussed here.

\section{Accidents}

The only external cost estimates that have a strong basis for inclusion in this study are those associated with accident-related injuries and fatalities. While there is information on employees' work days lost due to accidents, the value of that time is part of the marginal private cost of production and is therefore excluded from the external cost estimate.

There are several methods commonly used to provide minimum estimates of the value of a life. One major approach estimates the value of the lost productivity due to early mortality. Thus the productivity approach equates the value of a life to the value of a person's gross or net output. The major alternative approach estimates the value of life from evidence of public and private actions and statements which reveal the rate of tradeoff between life-threatening risk and money. While the range of values found in the literature is great, figures of from $\$ 300,000$ to $\$ 500,000$ (1978 dollars) are commonly used. For the purposes of this study a cost of $\$ 400,000$ per life lost will be used. In the absence of any information regarding the nature and severity of gas-related injuries, a cost of $\$ 40,000$ per injury will be used.

Accidents associated with natural gas mainly occur in the form of well blow-outs during drilling, release of sulfur compounds during processing and pipeline failures during transportation (EPA 1977). Liquified natural gas presents additional accident risks through uncontrolled vaporization, though there has not been a major accident of this type since the 1940s. Because of the difference in accident types and risks LNG is treated separately in this section. 
Well blow-outs are most likely to occur in drilling exploratory wells or in servicing producing wells. In either case, if the gas is released with sufficient impact equipment may be damaged and if the gas ignites both equipment and lives may be lost. While such accidents are infrequent the extent of the resultant damages may be great. The rate of occurence of injuries to industry workers in the extraction process is included in Table 17. While information on property damage associated with these accidents was not available, the social cost estimates will not be distorted since the losses of gas-producing companies will ultimately be passed on to consumers as a cost of production.

TABLE 17. Occupational Accident Rates for Extracting, Gathering, Processing, Transmitting and Distributing Natural Gas

$\frac{\text { Accident Rate per } 10^{6} \text { Btu of Gas Input to Process }}{\text { Fatalities }}$

Extraction

Offshore

Onshore

$6.9 \times 10^{-2}$
$8.1 \times 10^{-1}$

$3.0 \times 10^{-10}$

$1.1 \times 10^{-8}$
$1.3 \times 10^{-7}$

Gathering

Pipeline

$3.1 \times 10^{-2} \quad 1.1 \times 10^{-9}$

$2.5 \times 10^{-8}$

Processing

Natural Gas Liquid Hydrogen Sulfide
$4.1 \times 10^{-1}$
$3.7 \times 10^{-9}$
$1.9 \times 10^{-9}$
$9.7 \times 10^{-8}$
$5.1 \times 10^{-9}$

Transmission and

Distribution

Pipeline

$4.0 \times 10^{-1} \quad 1.4 \times 10^{-8}$

$3.2 \times 10^{-7}$

Source: Hittman Associates, Inc. 1974.

Gas processing carries the hazard of hydrogen sulfide removal. Releases of this gas may cause bronchial irritation and death. The rate of occurence of injuries from release of $\mathrm{H}_{2} \mathrm{~S}$ is included in Table 17. The accident rates in this table are standardized in terms of $10^{6} \mathrm{Btu}$. The rates have a range as low as 0.3 injuries $/ 10^{15}$ Btu processed. 
Most pipeline accidents result from either corrosion or outside forces which cause pipeline breaks. During 1975 there were 1,373 pipeline accidents reported in the U.S., over two-thirds of which resulted from damage by outside forces (mainly by construction or earth-moving equipment). The next largest number of accidents resulted from earthquakes and other natural forces. Most of the resultant fatalities and injuries affected nonemployees of pipeline companies (EPA 1977b). The accident rates for all pipeline related injuries are summarized in Table 18. While there have not been any major natural gasrelated disasters since the San Francisco earthquake and fire, pipeline failures in earthquake-prone areas could result in significant damages.

\begin{tabular}{|c|c|c|c|}
\hline & $\frac{\text { Accident Rate Per }}{\text { Employee }}$ & $\frac{6^{6} \text { Btu Delivered }}{\text { Nonemployee }}$ & $\frac{\text { to End Use Points }}{\text { Total }}$ \\
\hline Fatalities & $2.8 \times 10^{-10}$ & $5.0 \times 10^{-10}$ & $7.8 \times 10^{-10}$ \\
\hline Injuries & $2.1 \times 10^{-9}$ & $1.1 \times 10^{-8}$ & $1.3 \times 10^{-8}$ \\
\hline
\end{tabular}

Source: EPA 1977.

Most of the accident risk associated with LNG results from its cryogenic properties. Sudden vaporization may involve explosive force and as the vapor mixes with air it may be ignited. While there have been few major accidents, one in a Cleveland storage facility in 1944 had a strong negative impact on growth of the LNG industry. The resulting fire claimed 130 lives, left 300 people injured and did $\$ 10,000,000$ worth of damage (Simmons 1974; Van Horn and Wilson 1976). While accidents may occur in tankers, transfer points, liquefaction or vaporization plants, the greatest risks appear to be associated with storage facilities. Although accident probabilities have been the subject of considerable research, there is little data a'vailable to validate the engineering estimates. Thus, none of the associated social costs are incorporated in this study. 


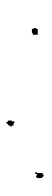




\section{AGGREGATION OF ESTIMATES}

Social costs vary with the source of natural gas supply, whether it is domestic or imported, conventional or synthetic and whether or not it is converted to LNG for transportation. This is because the main factors affecting the level of social cost are the marginal cost of production (excluding transmission related costs) and the marginal cost of environmental externalities. Variation in these two factors may lead to a wide range of social cost values across regions of the United States depending upon the primary source of natural gas in each region. The most economically efficient pattern of gas consumption should occur when the gas price used to determine consumption levels in a region is as close as possible to the actual social cost of natural gas delivered to buildings in that region. To develop such estimates of social costs, we examine the sources of supply to each state, summarize the social cost components and discuss the likely trends in regional cost variation.

\section{SOURCES OF GAS SUPPLY}

The U.S. gas supply is characterized by a diversity of sources and a broad range of costs. Because of the nature of the transmission system, neither the sources nor the costs are easily traced to the end user. What is generally referred to as natural gas may or may not originate in association with oil and may be synthesized from coal or organic materials. It may be produced from domestic wells either on- or offshore or may be imported, perhaps as LNG. Each of these different supply sources involves different stages in production and transmission and thus different social costs. Figure 10 shows the main steps in the flow of gas from the various sources to end users.

While onshore and offshore production differ to some degree in the type and extent of environmental impacts, their similarities are much greater than their differences. The technology of offshore production results in slightly more significant environmental impacts than onshore production does because the effluents are emitted to and contaminate water as well as the atmosphere. Once the gas reaches the gathering pipelines however, onshore and offshore gas are undifferentiable as indicated in Figure 10. 


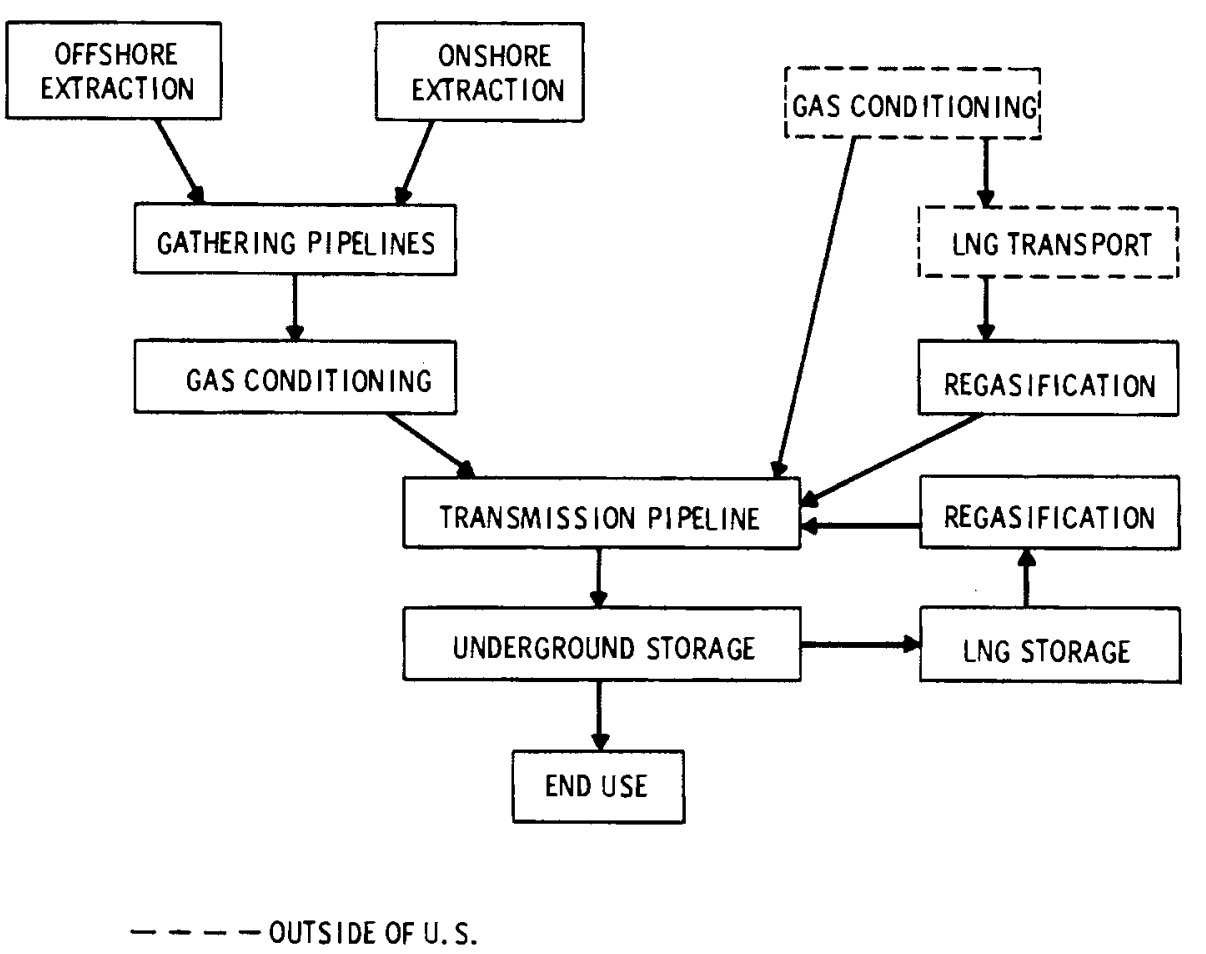

FIGURE 10. Gas Supply Stages

Imported gas is delivered to the U.S. from Canada in pipelines and LNG trucks, from ilexico via transmission pipelines, and from Algeria in LNG tankers. In the case of all imported gas the external costs associated with environmental or health damages resulting from gas production and conditioning are borne by the exporting country rather than by the U.S. Though imported gas is undifferentiable from domestic gas once in the transmission pipelines, LNG must first be regasified. Thus, it requires an additional process step with additional costs and risks. While the use of LNG has been growing, it currently constitutes less than $1 \%$ of total U.S. supply and is used mainly on the East Coast. Table 19 shows the quantities of gas imported annually since 1970 . 
TABLE 19. Imports of Natural Gas to the

United States, 1970-1977

\begin{tabular}{lrrrrr}
\multicolumn{5}{c}{ (Millions of Cubic } & Feet) \\
\cline { 6 - 7 } Year & \multicolumn{1}{c}{ Total } & \multicolumn{1}{c}{ Canada } & Mexico & Algeria \\
1977 & $1,010,431$ & 996,723 & 2,384 & 11,324 \\
1976 & 963,768 & 953,613 & 0 & 10,155 \\
1975 & 953,007 & 948,114 & 0 & 4,891 \\
1974 & 959,285 & 959,063 & 222 & 0 \\
1973 & $1,032,903$ & $1,027,216$ & 1,632 & 4,055 \\
1972 & $1,019,495$ & $1,009,092$ & 8,140 & 2,262 \\
1971 & 934,547 & 910,925 & 20,689 & 2,933 \\
1970 & 820,781 & 778,688 & 41,336 & 757
\end{tabular}

Source: Federal Energy Regulatory Commission.

It is expected that in the future an increasing proportion of the gas consumed will be synthetic natural gas (SNG) from coal gasification and similar processes. Since the private production costs and perhaps the external costs of SNG are higher than those for natural sources, increases in SNG use may strongly affect the marginal social costs of natural gas.

Since gas from various sources is blended in the transmission pipelines, it is quite difficult to determine where gas at any end use point originated. Figure 11 shows the location and direction of major gas flows in interstate markets but does not begin to indicate the complexity of the delivery system. Through simultaneous solution of a multi-equation model the FPC estimated the quantities of interstate and imported gas consumed in each state. Intrastate consumption estimates were added to the FPC estimates in Table 20 to provide estimates of the proportion of gas used in each state that originated onshore, offshore or as imports.

\section{SUMMARY OF COST ESTIMATES}

The components of the social cost of natural gas for which estimates could be developed within the scope of this study are marginal production and transmission costs, the cost of regulation administration, the cost of direct 


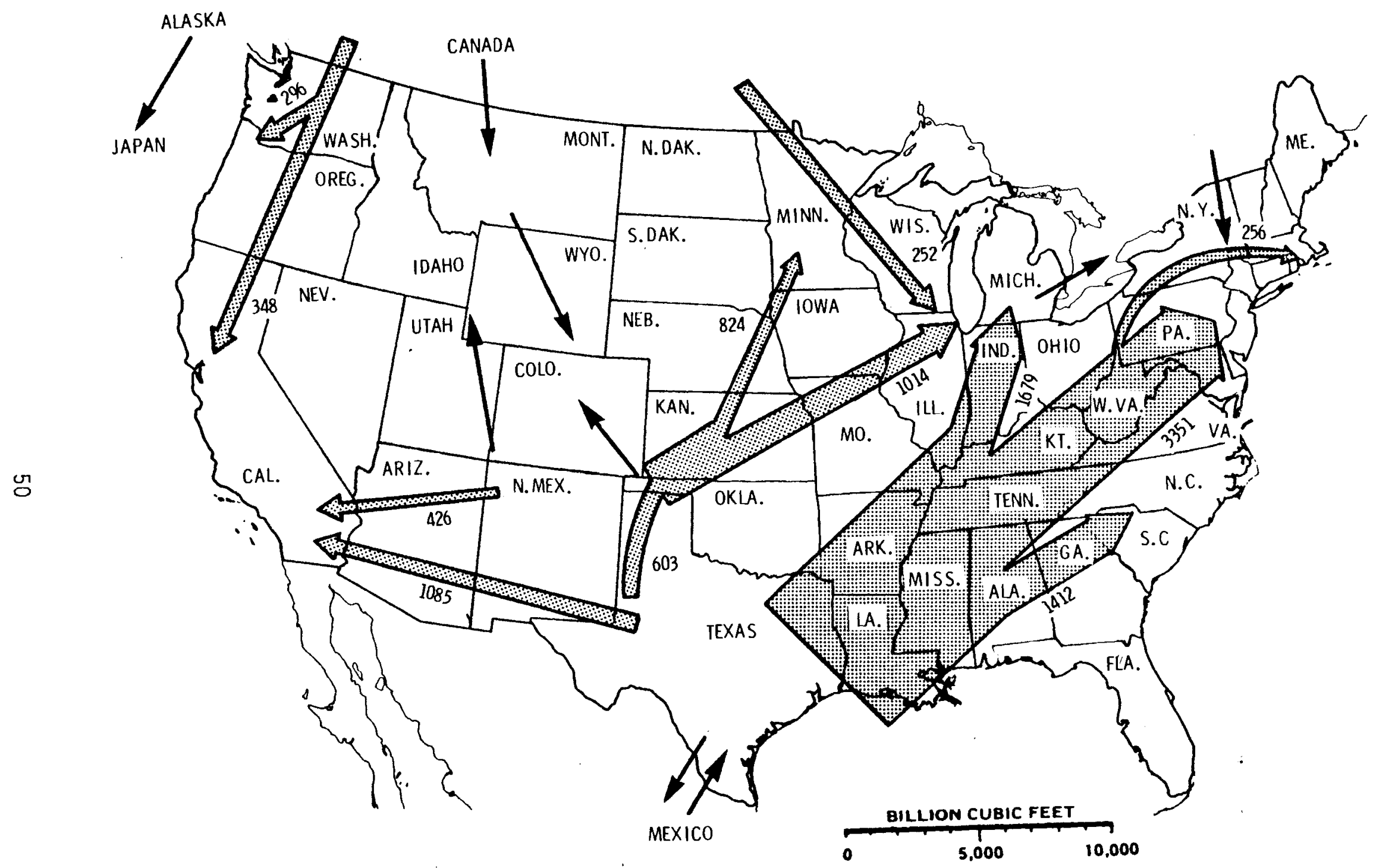

FIGURE 11. Natural Gas Transported in 1974 by FPC Regulated Pipelines 
TABLE 20. Estimated Gas Consumption for States by Source, 1974 (in 109 cf)

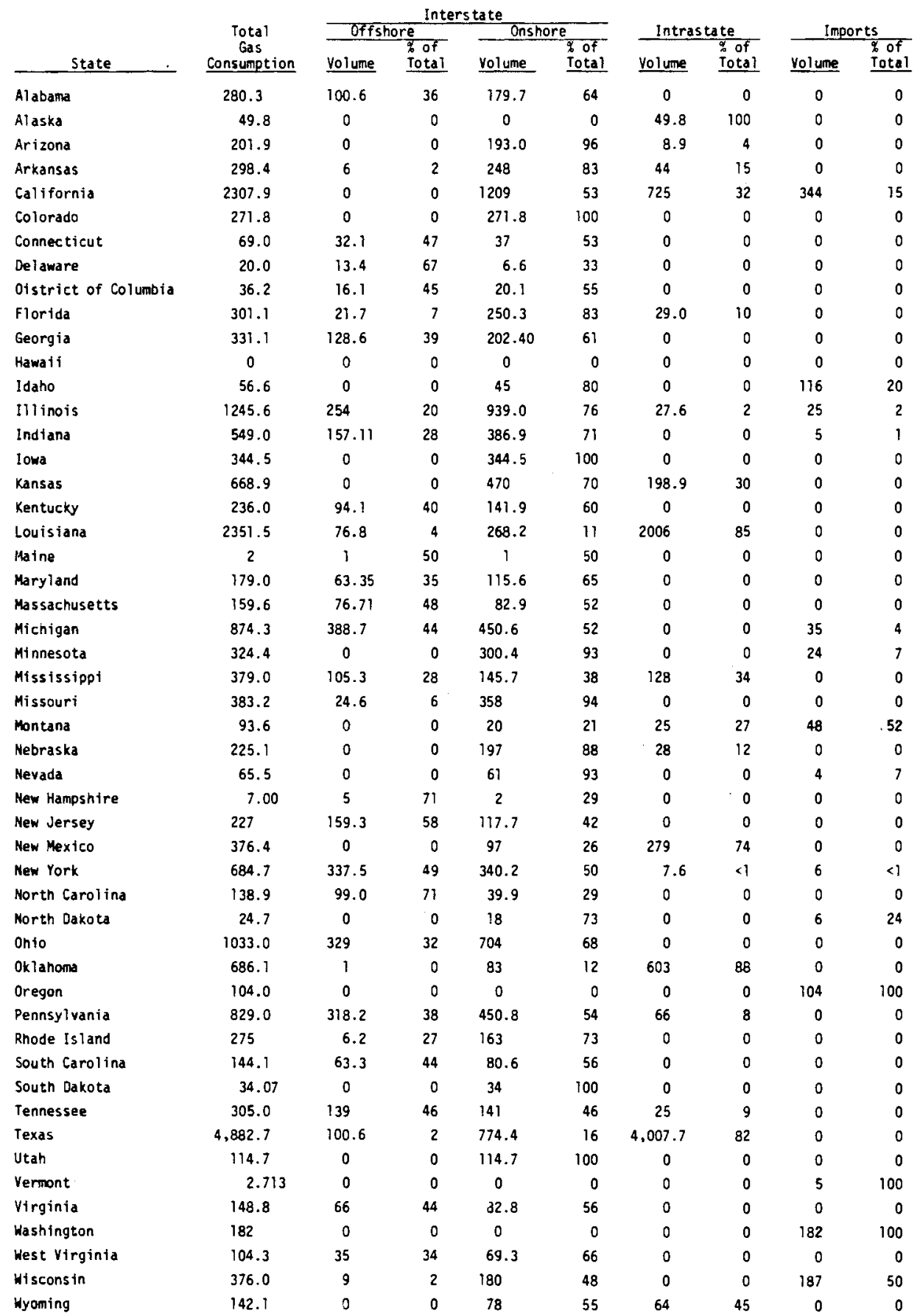

Sources: AGA 1975, FPC 1976. 
subsidies and the cost of accidental damage to life and limb. While the marginal private cost estimates represent relatively complete and certain information the external cost estimates have major gaps. Areas in which the information needed to develop cost estimates is either partially or totally lacking are:

- environmental damages due to emissions including impacts on vegetation, materials and health

- property damage due to accidents

- environmental damages due to LNG and SNG

- accident rates for LNG and SNG

If the use of SNG and imported LNG increases as projected, lack of information on their external costs may create a significant understatement of social cost for the regions where these supplies are used most.

Derivation of the estimates of marginal private costs of gas delivered to residences and commercial establishments was shown in Table 12. These estimates are an average of marginal costs for the nation expressed in 1978 dollars. The market costs are by far the most important element in the total marginal social cost of natural gas.

The total cost of regulation related to natural gas in 1977 was $\$ 55.2$ million (1978 dollars) or $\$ 0.0028 / 10^{6}$ Btu of marketed production. Using a conversion efficiency factor of 0.88 , computed from production statistics, (AGA 1978), the cost of regulation is $\$ 0.0032 / 10^{6}$ Btu delivered to end use. If this cost increases at only half of the present rate of $20 \%$ annually, the costs will be close to those shown in Table 21 .

TABLE 21. Projected Costs of Natural Gas Regulation

(1978 \$/106 Btu Delivered)

$\begin{array}{lll}\text { Year } & & \text { Cost } \\ 1985 & & 0.01 \\ 1990 & & 0.01 \\ 1995 & 0.02 \\ 2000 & 0.03\end{array}$


Funding of research and development subsidies for natural gas in 1978 totalled $\$ .0115 / 10^{6}$ Btu delivered to end use. Recently the real rate of increase in the relevant government budgets has been close to $12 \%$ annually. Projected costs based on this trend are shown in Table 22 .

TABLE 22. Projected Cost of Natural Gas Subsidization (1978 \$/106 Btu Delivered)

\begin{tabular}{ll} 
Year & Cost \\
\hline 1985 & 0.03 \\
1990 & 0.04 \\
1995 & 0.08 \\
2000 & 0.14
\end{tabular}

The escalation rates used for the real costs of both regulation and subsidization of natural gas production are conservative estimates based on the absolute growth in agency budgets. When the decline in gas production since 1970 is taken into account, the trend in public expenditure per Btu delivered shows a much higher rate of increase.

Fatality and injury rates per $10^{6}$ end use Btu of natural gas are summarized in Table 23. Since the data were reported (as shown in Table 17) as a rate per $10^{6}$ Btu of gas input to each process, conversion efficiency factors were used to convert all estimates to the rate per $10^{6}$ Btu delivered. These rates were then multiplied by the cost estimates per occurrence to estimate the social cost of fatalities and injuries per $10^{6}$ Btu delivered as shown in Table 24. Since no information was available as to the rate of change in the accident rate, it was assumed to be constant.

The estimated values for components of social cost are summarized in Table 25. These figures represent projections of marginal costs for the nation for the years from 1985 to 2000. According to these estimates the greatest rate of real increase in marginal costs occurs between 1990 and 1995. 
TABLE 23. Summary of Fatality and Injury Rates for Natural Gas Processes

\begin{tabular}{|c|c|c|c|c|c|}
\hline \multicolumn{3}{|c|}{ Fatalities } & \multicolumn{3}{|c|}{ Injuries } \\
\hline $\begin{array}{l}\text { Per } 10^{6} \text { Btu } \\
\text { Process Inputs }\end{array}$ & 1/C.E.F. (a) & $\begin{array}{l}\text { Per } 10^{6} \mathrm{Btu} \\
\text { in End Use }\end{array}$ & $\begin{array}{l}\text { Per } 10^{\delta} \text { Btu } \\
\text { Process Inputs }\end{array}$ & 1/C.E.F. (a) & $\begin{array}{l}\text { Per } 10^{6} \text { Btu } \\
\text { in End Use }\end{array}$ \\
\hline
\end{tabular}

Employees:

\begin{tabular}{|c|c|c|c|c|c|c|}
\hline \multicolumn{7}{|l|}{ Extraction } \\
\hline $\begin{array}{l}\text { Onshore } 80 \% \\
\text { Offshore } 20 \%\end{array}$ & $\begin{array}{l}8.1 \times 10^{-11} \\
6.9 \times 10^{-12}\end{array}$ & 1.19 & $7.9 \times 10^{-11}$ & $\begin{array}{l}3.6 \times 10^{-9} \\
3.0 \times 10^{-10}\end{array}$ & 1.19 & $3.5 \times 10^{-9}$ \\
\hline $\begin{array}{l}\text { Gathering } \\
\text { Pipeline }\end{array}$ & $3.1 \times 10^{-12}$ & 1.19 & $3.7 \times 10^{-12}$ & $1.1 \times 10^{-9}$ & 1.19 & $1.3 \times 10^{-9}$ \\
\hline NGL Separation & $4.1 \times 10^{-11}$ & 1.14 & $4.7 \times 10^{-11}$ & $3.7 \times 10^{-9}$ & 1.14 & $4.2 \times 10^{-9}$ \\
\hline $\mathrm{H}_{2} \mathrm{~S}$ Remova 1 & $2.1 \times 10^{-12}$ & 1.14 & $2.4 \times 10^{-12}$ & $1.9 \times 10^{-9}$ & 1.14 & $2.2 \times 10^{-9}$ \\
\hline $\begin{array}{l}\text { Transmission } \\
\text { Pipeline }\end{array}$ & $4.0 \times 10^{-11}$ & 1.04 & $4.2 \times 10^{-11}$ & $1.4 \times 10^{-8}$ & 1.04 & $1.5 \times 10^{-8}$ \\
\hline Storage & NA & NA & & NA & NA & \\
\hline Subtotal & & & $1.7 \times 10^{-10}$ & & & $2.6 \times 10^{-8}$ \\
\hline \multicolumn{7}{|l|}{ Nonemployees: } \\
\hline Subtota 1 & $5.0 \times 10^{-10}$ & 1.00 & $5.0 \times 10^{-10}$ & $1.1 \times 10^{-8}$ & 1.00 & $1.1 \times 10^{-8}$ \\
\hline Total & & & $6.7 \times 10^{-10}$ & & & $3.7 \times 10^{-8}$ \\
\hline
\end{tabular}

(a) Conversion Efficiency Factor

TABLE 24. Social Costs of Natural Gas Related Fatalities and Injuries

\begin{tabular}{|c|c|c|}
\hline & $\begin{array}{l}\text { Fatalities per } \\
10^{6} \text { Btu Delivered } \\
\end{array}$ & $\begin{array}{c}\text { Injuries per } \\
10 \frac{6}{\text { Btu Del ivered }}\end{array}$ \\
\hline Rate & $6.7 \times 10^{-10}$ & $3.7 \times 10^{-8}$ \\
\hline Cost per Occurrence & $\$ 400,000$ & $\$ 40,000$ \\
\hline $\begin{array}{l}\text { Cost per } 10^{6} \mathrm{Btu} \\
\text { Delivered }\end{array}$ & $\$ .0003$ & $\$ .0015$ \\
\hline
\end{tabular}

TABLE 25. Summary of Social Cost Estimates for Natural Gas (1978 \$ per 106 Btu)

\begin{tabular}{|c|c|c|c|c|c|c|c|}
\hline & \multicolumn{2}{|c|}{ Marginal Private Cost } & \multicolumn{3}{|c|}{ External Cost } & \multirow{2}{*}{$\frac{\text { Total Margina }}{\text { Residential }}$} & \multirow{2}{*}{$\frac{\text { Social cost }}{\text { Commercial }}$} \\
\hline & Residential & Commercial & Regulation & Subsidization & Accidents & & \\
\hline 1985 & 4.00 & 3.85 & .01 & .03 & .0018 & 4.04 & 3.89 \\
\hline 1990 & 4.25 & 4.11 & .01 & .04 & .0018 & 4.30 & 4.16 \\
\hline 1995 & 5.13 & 4.98 & .02 & .08 & .0018 & 5.23 & 5.08 \\
\hline 2000 & 5.93 & 5.78 & .03 & .14 & .0018 & 6.10 & 5.95 \\
\hline
\end{tabular}




\section{REGIONAL COST ESTIMATES}

Projection of regional marginal social cost estimates for fuels is necessary to avoid inefficient resource allocation in those states where fuel costs diverge most sharply from the national average. A method of deriving such projections from average residential gas prices and national marginal cost is given in Table 26 . This table shows gas prices by state as a percentage of the national average price, from which a rough estimate of the trend in state prices relative to national price was derived. This projected percentage figure is multiplied by the projected 1985 national marginal social cost estimate to estimate relative social cost levels by state.

This method of deriving regional marginal cost estimates assumes that the proportionality between a state's marginal cosit and national marginal cost is the same as the proportionality between that state's average cost and national average cost. The relative social cost levels in the various states will be affected in the future by the increasing use of LNG and SNG in some states. If the social cost impacts of these supply changes were identified, the estimates of state costs as a percentage of national cost could be refined to permit projection of regional social costs beyond 1985. 
TABLE 26. Derivation of State Marginal Social Costs for Residential Gas Use per 106 Btu

\begin{tabular}{|c|c|c|c|c|c|c|c|c|}
\hline & \multicolumn{2}{|c|}{1970} & \multicolumn{2}{|c|}{1975} & \multicolumn{2}{|c|}{1977} & \multicolumn{2}{|c|}{1985 (1978 Dollars) } \\
\hline & Price & $\begin{array}{c}\text { Q of } \\
\text { Mational } \\
\text { Price } \\
\end{array}$ & Price & $\begin{array}{l}\text { Sof of } \\
\text { Mational } \\
\text { Price } \\
\end{array}$ & Price & $\begin{array}{l}\text { Q of } \\
\text { National } \\
\text { Price } \\
\end{array}$ & $\begin{array}{l}\text { Projected } \\
\text { Percentage of } \\
\text { Mational Price } \\
\end{array}$ & $\begin{array}{l}\text { Projected } \\
\text { Marginal } \\
\text { Soctal Cost } \\
\end{array}$ \\
\hline United States & 1.06 & 100 & 1.69 & 100 & 2.33 & 100 & 100 & 4.04 \\
\hline $\begin{array}{l}\text { Region I } \\
\text { Connecticut } \\
\text { Maine } \\
\text { Massachusetts } \\
\text { New Hampshire } \\
\text { Rhode Is land } \\
\text { Vermont }\end{array}$ & $\begin{array}{l}1.93 \\
2.89 \\
1.87 \\
1.77 \\
1.76 \\
1.78\end{array}$ & $\begin{array}{l}182 \\
273 \\
176 \\
167 \\
166 \\
168\end{array}$ & $\begin{array}{l}3.27 \\
4.25 \\
3.20 \\
2.46 \\
3.16 \\
2.80\end{array}$ & $\begin{array}{l}193 \\
251 \\
189 \\
146 \\
187 \\
166\end{array}$ & $\begin{array}{l}4.30 \\
5.13 \\
4.08 \\
3.36 \\
4.04 \\
3.80\end{array}$ & $\begin{array}{l}185 \\
220 \\
175 \\
144 \\
173 \\
163\end{array}$ & $\begin{array}{l}185 \\
220 \\
180 \\
145 \\
175 \\
165\end{array}$ & $\begin{array}{l}7.47 \\
8.89 \\
7.27 \\
5.86 \\
7.07 \\
6.67\end{array}$ \\
\hline $\begin{array}{l}\text { Region II } \\
\text { New Jersey } \\
\text { Mew York } \\
\text { Puerto Rico } \\
\text { Virgin Islands }\end{array}$ & $\begin{array}{c}1.62 \\
1.38 \\
\because \because \\
-\cdots\end{array}$ & $\begin{array}{r}153 \\
130 \\
-- \\
--\end{array}$ & $\begin{array}{c}2.59 \\
2.43 \\
--\end{array}$ & $\begin{array}{c}153 \\
144 \\
\because- \\
-\end{array}$ & $\begin{array}{c}3.42 \\
3.26 \\
\because- \\
.-\end{array}$ & $\begin{array}{r}147 \\
140 \\
\because- \\
--\end{array}$ & $\begin{array}{r}150 \\
140 \\
-. \\
-\end{array}$ & $\begin{array}{c}6.06 \\
5.66 \\
-- \\
--\end{array}$ \\
\hline $\begin{array}{l}\text { Region III } \\
\text { delaware } \\
\text { District of Coluabia } \\
\text { Maryland } \\
\text { Pennsylvania } \\
\text { Virginia } \\
\text { West Virginia }\end{array}$ & $\begin{array}{l}1.50 \\
1.44 \\
1.43 \\
1.17 \\
1.42 \\
.87\end{array}$ & $\begin{array}{r}142 \\
136 \\
135 \\
110 \\
134 \\
82\end{array}$ & $\begin{array}{l}2.34 \\
2.40 \\
2.31 \\
1.90 \\
2.29 \\
1.47\end{array}$ & $\begin{array}{r}138 \\
142 \\
137 \\
112 \\
136 \\
87\end{array}$ & $\begin{array}{l}3.16 \\
3.27 \\
3.15 \\
2.56 \\
2.99 \\
2.11\end{array}$ & $\begin{array}{r}136 \\
140 \\
135 \\
110 \\
128 \\
91\end{array}$ & $\begin{array}{r}140 \\
140 \\
135 \\
110 \\
130 \\
90\end{array}$ & $\begin{array}{l}5.66 \\
5.66 \\
5.45 \\
4.44 \\
5.25 \\
3.64\end{array}$ \\
\hline $\begin{array}{l}\text { Region IV } \\
\text { Alabama } \\
\text { Florida } \\
\text { Georgla } \\
\text { Kentucky } \\
\text { kississippi } \\
\text { Morth Carolina } \\
\text { South Carolina } \\
\text { Tennessee }\end{array}$ & $\begin{array}{r}1.10 \\
1.81 \\
.98 \\
.84 \\
.88 \\
1.29 \\
1.34 \\
.89\end{array}$ & $\begin{array}{r}104 \\
171 \\
92 \\
79 \\
83 \\
122 \\
126 \\
84\end{array}$ & $\begin{array}{l}1.72 \\
2.78 \\
1.75 \\
1.30 \\
1.41 \\
2.02 \\
2.08 \\
1.33\end{array}$ & $\begin{array}{r}102 \\
164 \\
104 \\
77 \\
83 \\
120 \\
123 \\
79\end{array}$ & $\begin{array}{l}2.21 \\
3.30 \\
2.26 \\
1.83 \\
2.05 \\
2.83 \\
2.67 \\
1.78\end{array}$ & $\begin{array}{r}95 \\
142 \\
97 \\
79 \\
88 \\
121 \\
115 \\
76\end{array}$ & $\begin{array}{r}100 \\
150 \\
100 \\
80 \\
85 \\
120 \\
120 \\
80\end{array}$ & $\begin{array}{l}4.04 \\
6.06 \\
4.04 \\
3.23 \\
3.43 \\
4.85 \\
4.85 \\
3.23\end{array}$ \\
\hline $\begin{array}{l}\text { Region v } \\
\text { Mllinots } \\
\text { Indiana } \\
\text { Michigan } \\
\text { Hinnesota } \\
\text { Ohio } \\
\text { Ohisconsin }\end{array}$ & $\begin{array}{l}1.02 \\
1.05 \\
1.00 \\
1.08 \\
.89 \\
1.21\end{array}$ & $\begin{array}{r}96 \\
99 \\
94 \\
102 \\
84 \\
114\end{array}$ & $\begin{array}{l}1.58 \\
1.45 \\
1.60 \\
1.59 \\
1.51 \\
1.71\end{array}$ & $\begin{array}{r}93 \\
86 \\
95 \\
94 \\
89 \\
101\end{array}$ & $\begin{array}{l}2.26 \\
2.06 \\
2.20 \\
2.14 \\
2.23 \\
2.46\end{array}$ & $\begin{array}{c}97 \\
88 \\
94 \\
92 \\
96 \\
106\end{array}$ & $\begin{array}{r}95 \\
90 \\
95 \\
95 \\
95 \\
105\end{array}$ & $\begin{array}{l}3.84 \\
3.64 \\
3.84 \\
3.84 \\
3.84 \\
4.24\end{array}$ \\
\hline $\begin{array}{l}\text { Region VI } \\
\text { Arkansas } \\
\text { Louisiana } \\
\text { Mew Mexico } \\
\text { Oklahoma } \\
\text { Texas }\end{array}$ & $\begin{array}{l}.78 \\
.75 \\
.84 \\
.80 \\
.92\end{array}$ & $\begin{array}{l}74 \\
71 \\
79 \\
75 \\
87\end{array}$ & $\begin{array}{l}1.12 \\
1.32 \\
1.37 \\
1.15 \\
1.47\end{array}$ & $\begin{array}{l}66 \\
78 \\
81 \\
68 \\
87\end{array}$ & $\begin{array}{l}1.46 \\
1.93 \\
2.00 \\
1.73 \\
2.36\end{array}$ & $\begin{array}{r}63 \\
83 \\
86 \\
74 \\
101\end{array}$ & $\begin{array}{l}65 \\
80 \\
85 \\
70 \\
95\end{array}$ & $\begin{array}{l}2.63 \\
3.23 \\
3.43 \\
2.83 \\
3.84\end{array}$ \\
\hline $\begin{array}{l}\text { Region VII } \\
\text { Iowa } \\
\text { Kansas } \\
\text { Missouri } \\
\text { Nebraskd }\end{array}$ & $\begin{array}{l}.96 \\
.69 \\
.93 \\
.86\end{array}$ & $\begin{array}{l}91 \\
65 \\
88 \\
81\end{array}$ & $\begin{array}{l}1.41 \\
1.97 \\
1.45 \\
1.26\end{array}$ & $\begin{array}{l}83 \\
57 \\
86 \\
75\end{array}$ & $\begin{array}{l}1.93 \\
1.51 \\
2.08 \\
1.74\end{array}$ & $\begin{array}{l}83 \\
65 \\
89 \\
75\end{array}$ & $\begin{array}{l}85 \\
60 \\
90 \\
75\end{array}$ & $\begin{array}{l}3.43 \\
2.42 \\
3.64 \\
3.03\end{array}$ \\
\hline $\begin{array}{l}\text { Region VIII } \\
\text { Colorado } \\
\text { Montana } \\
\text { North Dakota } \\
\text { South Dakota } \\
\text { Utah } \\
\text { Wyoming }\end{array}$ & $\begin{array}{r}.71 \\
.84 \\
1.05 \\
1.04 \\
.70 \\
.65\end{array}$ & $\begin{array}{l}67 \\
79 \\
99 \\
98 \\
66 \\
61\end{array}$ & $\begin{array}{l}1.16 \\
1.18 \\
1.50 \\
1.40 \\
1.12 \\
.99\end{array}$ & $\begin{array}{l}69 \\
70 \\
89 \\
83 \\
66 \\
59\end{array}$ & $\begin{array}{l}1.71 \\
1.69 \\
2.03 \\
1.84 \\
1.55 \\
1.66\end{array}$ & $\begin{array}{l}73 \\
73 \\
87 \\
79 \\
67 \\
71\end{array}$ & $\begin{array}{l}70 \\
75 \\
90 \\
80 \\
70 \\
65\end{array}$ & $\begin{array}{l}2.83 \\
3.03 \\
3.64 \\
3.23 \\
2.83 \\
2.63\end{array}$ \\
\hline $\begin{array}{l}\text { Region Ix } \\
\text { Arizond } \\
\text { Caifformia } \\
\text { Hawait } \\
\text { Mevada }\end{array}$ & $\begin{array}{r}1.14 \\
.93 \\
3.56 \\
1.31\end{array}$ & $\begin{array}{r}108 \\
88 \\
336 \\
124\end{array}$ & $\begin{array}{l}1.83 \\
1.52 \\
7.97 \\
1.81\end{array}$ & $\begin{array}{r}108 \\
90 \\
472 \\
107\end{array}$ & $\begin{array}{l}2.59 \\
1.81 \\
8.42 \\
2.17\end{array}$ & $\begin{array}{c}111 \\
78 \\
361 \\
93\end{array}$ & $\begin{array}{r}110 \\
85 \\
360 \\
95\end{array}$ & $\begin{array}{r}4.44 \\
3.43 \\
14.54 \\
3.84\end{array}$ \\
\hline $\begin{array}{l}\text { Region } x \\
\text { Alaska } \\
\text { Idaho } \\
\text { Oregon } \\
\text { Washington }\end{array}$ & $\begin{array}{l}1.42 \\
1.34 \\
1.44 \\
1.29\end{array}$ & $\begin{array}{l}134 \\
126 \\
136 \\
122\end{array}$ & $\begin{array}{l}1.48 \\
2.25 \\
2.41 \\
2.12\end{array}$ & $\begin{array}{r}88 \\
133 \\
143 \\
125\end{array}$ & $\begin{array}{l}1.70 \\
3.20 \\
3.29 \\
3.02\end{array}$ & $\begin{array}{r}73 \\
137 \\
141 \\
130\end{array}$ & $\begin{array}{r}70 \\
135 \\
140 \\
130\end{array}$ & $\begin{array}{l}2.83 \\
5.45 \\
5.66 \\
5.25\end{array}$ \\
\hline
\end{tabular}

Source: AGA 1978. 


\section{CONCLUSIONS}

The total cost to society of natural gas production and consumption is made up of both market (private) and nonmarket (external) costs. Both types of costs are likely to increase over time as lower quality resources are exploited.

Estimates of the marginal private cost of natural gas were compared using three methodologies, namely, production costs basis, econometric supply-demand equilibrium, and parity with competing fuels. Each method indicated rapidly increasing marginal costs. Specific findings related to price estimation are discussed below. All prices are in 1978 dollars.

- 1976 production costs based on FPC procedures have been recomputed at $\$ 1.90 / 10^{3} \mathrm{cf}$. Drilling costs have increased at a $4.5 \%$ annual rate in real terms. Unless the productivity trend is altered, marginal production costs will continue to escalate.

- Marginal private costs include not only production costs but nonproduction costs such as changes in the reservation price due to increased demand for environmentally clean fuel and increased prices of competitive fuels.

- The supply-demand equilibrium price estimates for natural gas depend heavily on the assumptions underlying both the resource base and demand adjustments to prior gas curtailments.

- Industrial distillate $0 i 1$ is the fuel with which natural gas competes at the margin. Thus, the parity price of gas is projected to move in a parallel manner with the price of this $0 i 1$.

- $0 i 1$ prices are most often assumed to remain constant in real dollars until sometime in the 1985 to 1990 period. At this latter time, oil prices begin to escalate rapidly to the cost level of synthetic fuels.

Estimation of the marginal private cost of gas at the retail level involves two additional considerations. Supplemental gas supplies are comingled with 
natural gas, and the user incurs transmission and distribution charges. Specific observations on these two cost aspects are:

- SNG from coal gasification projects can be viewed as the marginal supplemental gas supply. The marginal private cost of SNG is higher in the near-term than mid-term when technological improvements and scale economies may be realized. Increases in resource costs increase the marginal private cost of SNG in the long-term.

- Marginal transmission and distribution costs are relatively small due to the dominance of high fixed costs. However, the cost of fuel consumed in this stage increases rapidly and marginal transportation costs increase in future years.

- The marginal cost of natural gas is best measured by a weighted average of the marginal costs of natural and supplemental gas supplies.

External costs are those costs which are not borne by the producers and consumers of a good, such as natural gas. These costs result from the effects of emissions, visual impacts and accidents as well as regulation and subsidization of the gas industry. Findings in regard to external costs are:

- LNG and SNG have higher accident risk and emission levels than do conventional natural gas. Thus their increased use will lead to increasing external costs for natural gas.

- The effects of emissions from natural gas processes cannot be accurately quantified from presently available information. Research is needed involving both models and data for emissions dispersion and damage functions.

- Costs of regulation and research have been increasing rapidly but are insignificant in comparison to private production costs.

- It was not possible to develop comprehensive estimates of social cost since only a small fraction of the costs resulting from external effects were documentable within the scope of this study.

Regional or state estimates of natural gas social costs are derived for 1985. The degree of variation in these costs indicates that distortions in resource allocation would result from use of a single national cost estimate. 


\section{REFERENCES}

American Gas Association. 1975. Gas Facts: 1974 Data. A Statistical Record of the Gas Utility Industry. AGA, Arlington, Virginia.

American Gas Association. 1977a. "Impact of the President's Proposed \$1.75/Mcf New Gas Price Ceiling on Domestic Gas Production." Energy Analysis. May 1977.

American Gas Association. 1977b. "Impacts on Consumer's Prices of the House and Senate New Gas Pricing Legislation." Energy Analysis. October 21, 1977.

American Gas Association. 1978. Gas Facts: 1977. A Statistical Record of the Gas Utility Industry. AGA, Arlington, Virginia.

Bause11, C. W., Jr. 1978. An Economic Impact of Ambient Air Quality Standards for Sulfur Oxides. Division of Research, Department of Economic and Community Development, Annapol is, Maryland.

Brannon, G. M. 1974. Energy Taxes and Subsidies. Ballinger Publishing Corporation, Cambridge, Massachusetts.

Commission on Natural Resources. 1975. Air Quality and Stationary Source Emission Control. National Academy of Sciences, National Academy of Engineering, National Research Council for the Committee on Public Works, U.S. Senate, Washington, D.C.

Cone, B. W., et a1. 1978. An Analysis of Federal Incentives Used to Stimulate Energy Production. PNL-24T0 Rev., Pacific Northwest Laboratory, Richland, Washington.

Congressional Budget Office (CBO). 1977. Natural Gas Pricing Proposals: A Comparative Analysis. CBO, Washington, D.C.

Daya 1, R. 1977. Equation Specification for World Integrated Model (WIN). Case Western Reserve University, Cleveland, Ohio.

DOE-EIA. 1978. See Energy Information Administration, 1978.

Edison Electric Institute. 1976. Economic Growth in the Future. McGraw-Hi11, New York, New York.

Environmental Protection Agency. 1977a. National Air Quality and Emmissions Trends Report. EPA-450/1-77-002, EPA, Research Triangle Park, North Carolina.

Environmental Protection Agency. 1977b. Accidents and Unscheduled Events Associated with Non-nuclear Energy Resources and Technology. EPA-600/7-77-016, Interagency Energy-Environmental Research and Development Program Report, EPA, Washington, D.C. 
Energy Information Administration. June 14, 1978. An Evaluation of Natural Gas Pricing Proposal. Memorandum \#AM/IA-7802, by the Applied Analysis Natural Gas Pricing Proposal Team, EIA, U.S. Department of Energy, Washington, D.C.

Erickson, E., and the Natural Gas Supply Committee. 1977. The Net Benefits to the American Economy of Deregulation of the Price of New Gas.

Executive Office of the President (EOP). 1977. Estimates of Producer Revenues and Consumer Costs under Decontrol. EOP, Washington, D.C.

Federal Power Commission. 1976. "Natural Gas Transported in 1974 by FPC Regulated Pipelines." FPC Staff Report, FPC, Washington, D.C.

Finklea, J. F., et al. 1977. "The Role of Environmental Heal th Assessment in the Control of Air Pollution." in Advances in Environmental Science and Technology. Vol. 7, J. N. Pitts and R. L. Metcalf, eds. John Wiley and Sons, Inc., New York.

Foster Associates, Inc. 1977. Natural Gas Pricing Alternatives. Report to Natural Gas Supply Committee.

Foster Associates, Inc. 1978. Fuel and Energy Price Forecasts (2 Vols.). Prepared for the Electric Power Research Institute, Palo Alto, California.

Hittman Associates, Inc. 1977. Environmental Impacts, Efficiency and Cost of Energy Supply and End Use. Vol. I PB-238-784, Available from National Technical Information Service, Springfield, Virginia.

House Energy and Power Subcommittee Staff. 1977. Economic Analys is of Natural Gas Policy Alternatives. U.S. House of Representatives, Washington, D.C.

Institute of Gas Technology. 1977. Analyses of New Gas Supplies and Energy Costs Under the President's National Energy Plan and Three Alternative Regulatory Policies." Energy Topics. IEIT, Chicago, Illinois.

Institute for Gas Technology. 1978. "A Critique of Natural Gas Pricing Alternatives." Energy Topics, Apri1 10, 1978.

Leung, S., et al. 1978. Methodologies for Valuation of Agricultural Crop Yield Changes: A Review. EPA-600/5-78-018, Corvallis Environmental Research Laboratory, Corvallis, Oregon.

Lin, B., et al. 1976. Physical and Economic Damage Functions for Air Pollutants by Receptor. EPA-600/5-76-011. EPA Contract No. 68-01-2968, MRI Project No. 4004-D. Prepared for Corvall is Environmental Research Laboratory, Corvallis, Oregon.

Mäler, K. G., and R. E. Wyzga. 1976. Economic Measurement of Environmental Damage. Organization for Economic Cooperation and Development. 
Nieves, L. A., et al. 1979. Evaluation of Resource Impact Factors Versus Social Costs in Determining Building Energy Standard Levels, PNL-3087, Pacific Northwest Laboratory, Richland, Washington.

North, W. D., and M. W. Merkhofer. 1975. "Analys is of Alternative Emissions Control Strategies." Air Quality and Stationary Source Emission Control. National Academy of Sciences, Washington, D.C.

Parent, J., and H. Linden. 1979. Energy Perspectives. Monograph Gas Research Institute, Chicago, I11inois.

Office of Policy and Evaluation. August 28, 1978. NESS Reference Projections. Draft. U.S. Department of Energy, Washington, D.C.

OPE. 1978. See Office of Policy and Evaluation, 1978.

Organization for Economic Cooperation and Development. 1972. Environmental Damage Costs.

Simmons, J. A. 1974. Risk Assessment of Storage and Transport of Liquefied Natural Gas and Liquefied Petroleum Gas. Science Applications, Inc. PB-247-415, Available from National Technical Information Service, Springfield, Virginia.

Van Horn, A. J., and R. Wilson. 1976. Liquefied Natural Gas: Safety Issues, Public Concerns and Decision Making. BNL-22284, Brookhaven National Laboratory, Upton, New York.

Wilson, S. U., et a1. 1978. Final Report of Florida Sulfur Oxides Study. Prepared by Florida Sulfur Oxides Study, Inc., for Florida Environmenta1 Regulation Commission, Tallahassee, Florida.

Workshop on Al ternative Energy Strategies (WAES). 1977. Energy: Global Prospects 1985-2000. McGraw-Hi11, New York.

H. Zinder and Associates, Inc. 1975. UDC Filing in Docket No. RM75-19, Statement 2, Exhibit A, Schedule 5, Zinder Interstate Mode1. Public Document Room, Washington, D.C. 

PNL -3091

UC-95d

\section{DISTRIBUTION}

No. of

Copies

\section{$\underline{\text { OFFSITE }}$}

A. A. Churm

DOE Patent Division

9800 S. Cass Avenue

Argonne, IL 60439

27 DOE Technical Information Center

50 J. Shivar

U.S. Department of Energy

Washington, DC 20545

J. Binkley

U.S. Department of Energy

Washington, DC 20545

M. Savitz

U.S. Department of Energy

Washington, DC 20545

J. Cable

U.S. Department of Energy

Washington, DC 20545

P. Back

U.S. Department of Energy

Washington, DC 20545

J. Wi11man

U.S. Department of Energy

Washington, DC 20545

C. L. McDonald

Mathematical Sciences Northwest, Inc.

P.0. Box 1887

Bellevue, WA 98009

J. R. Lemon

Monmouth College

Monmouth, IL 61462

W. Wilson

Conservation Foundation

1717 Mass. Ave. N.W.

Washington, DC 20036
No. of

Copies

ONSITE

DOE Richland Operations

H. E. Ransom

41 Pacific Northwest Laboratory

R. C. Adams

J. W. Currie

D. E. Deonigi

T. J. Foley

L. A. Nieves (10)

Economics Library (20)

Technical Information Files (5)

Publishing Coordination WI (2) 


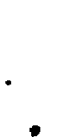

